\title{
A Competitive Pull-down Assay Using G-quadruplex DNA Linked Magnetic Nanoparticles to Determine Specificity of G- quadruplex Ligands
}

Deepanjan Panda ${ }^{\mathrm{a}}$, Puja Saha ${ }^{\mathrm{a}}$, Ritapa Chaudhuri ${ }^{\mathrm{a}}$, Thumpati Prasanth ${ }^{\mathrm{a}, \mathrm{b}}$, Velayutham

$$
\text { Ravichandiran }^{\mathrm{b}} \text { and Jyotirmayee Dash }{ }^{\mathrm{a} *}
$$

aSchool of Chemical Sciences, Indian Association for the Cultivation of Science, Jadavpur, Kolkata, India ${ }^{b}$ National Institute of Pharmaceutical Education and Research, Jadavpur, Kolkata, India Correspondence should be addressed to J.D. (ocjd@,iacs.res.in) 
1.0 General information: All solvents and reagents were purified by standard techniques reported in Armarego, W. L. F., Chai, C. L. L., Purification of Laboratory Chemicals, 5th edition, Elsevier, 2003; or used as supplied from commercial sources (Sigma-Aldrich Corporation ${ }^{\circledR}$ unless stated otherwise). All reactions were generally carried out under inert atmosphere unless otherwise noted. TLC was performed on Merck Kieselgel 60 F254 plates, and spots were visualized under UV light. Products were purified by flash chromatography on silica gel (100-200 mesh, Merck). ${ }^{1} \mathrm{H}$ and ${ }^{13} \mathrm{C}$ NMR spectra were recorded on either Bruker AVANCE 500 (500 MHz and $125 \mathrm{MHz}$ ), or JEOL $400(400 \mathrm{MHz}$ and $100 \mathrm{MHz}$ ) instruments using deuterated solvents as detailed and at ambient probe temperature $(300 \mathrm{~K})$. Chemical shifts are reported in parts per million ( $\mathrm{ppm}$ ) and are referred to the residual solvent peak. The following notations are used: singlet $(\mathrm{s})$; doublet $(\mathrm{d})$; triplet $(\mathrm{t})$; quartet $(\mathrm{q})$; multiplet (m); broad (br). Coupling constants are quoted in Hertz and are denoted as $J$. Mass spectra were recorded on a Micromass ${ }^{\circledR}$ Q-Tof $($ ESI) spectrometer.

2.0 General procedure for the preparation of dialkyne 4-6 (GP-1). To a solution of diiodo compound $(0.714 \mathrm{mmol})$ in $\mathrm{Et}_{3} \mathrm{~N}(5 \mathrm{~mL}), \mathrm{Pd}\left(\mathrm{PPh}_{3}\right)_{2} \mathrm{Cl}_{2}(50.11 \mathrm{mg}, 0.0714 \mathrm{mmol})$ and $\mathrm{CuI}$ (27.19 $\mathrm{mg}, 0.143 \mathrm{mmol}$ ) were added at room temperature. The mixture was stirred for $30 \mathrm{~min}$ and then TMS-Acetylene $(0.508 \mathrm{~mL}, 3.57 \mathrm{mmol})$ was added drop wise. The resulting mixture was stirred under an argon atmosphere for $12 \mathrm{~h}$. The solvents were concentrated, washed with brine, and dried over anhydrous $\mathrm{Na}_{2} \mathrm{SO}_{4}$. The crude product was purified by column chromatography and the product was stirred with 5 equivalents $\mathrm{K}_{2} \mathrm{CO}_{3}$ in methanol/ $\mathrm{CH}_{2} \mathrm{Cl}_{2}$ solution under an argon atmosphere for $4 \mathrm{~h}$. The solvents were concentrated, washed with brine, and dried over anhydrous $\mathrm{Na}_{2} \mathrm{SO}_{4}$. The crude product was purified by column chromatography. 


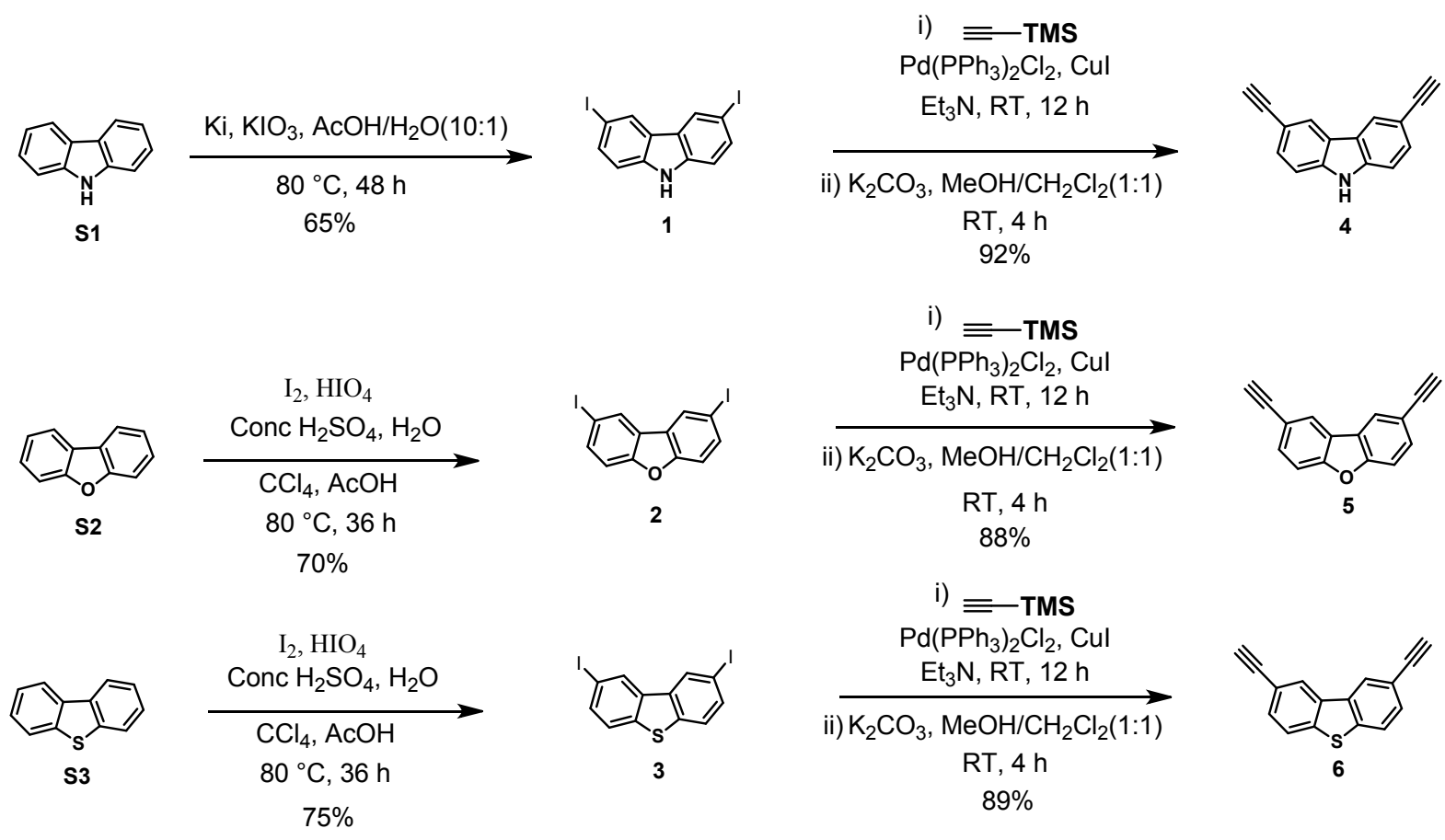

Scheme S1. Synthesis of dialkyne derivatives of carbazole, dibenzofuran and dibenzothiophene.

(a) Preparation of 5: Following the GP-1, compound S2 (300 mg) afforded the dialkyne 4 (135.86 mg, 88\%) as brown powder. ${ }^{1} \mathrm{H}$ NMR (400 MHz, $\left.\mathrm{CDCl}_{3}\right): 8.07(\mathrm{~s}, 2 \mathrm{H})$, $7.61\left(\mathrm{dd}, 2 \mathrm{H}, J_{1}=8.4, J_{2}=1.8\right), 7.52(\mathrm{~d}, 2 \mathrm{H}, J=8.4), 3.10(\mathrm{~s}, 2 \mathrm{H}) .{ }^{13} \mathrm{C}$ NMR $(100 \mathrm{MHz}$, $\mathrm{CDCl}_{3}$ ): 156.6, 132.0, 125.0,123.9, 117.3, 112.1, 83.6, (one carbon peak merged with $\mathrm{CDCl}_{3}$ peak). HRMS (ESI) calculated for $\left[\mathrm{C}_{16} \mathrm{H}_{8} \mathrm{O}\right]$ is 216.0575 , found 216.0582 .

(b) Preparation of 6: Following the GP-1, compound $3(311.3 \mathrm{mg})$ afforded the dialkyne $6(147.62 \mathrm{mg}, 89 \%)$ as brown powder. ${ }^{1} \mathrm{H}$ NMR (400 MHz, $\left.\mathrm{CDCl}_{3}\right): 8.2(\mathrm{~s}, 2 \mathrm{H})$, $7.78(\mathrm{~d}, 2 \mathrm{H}, J=8), 7.57\left(\mathrm{dd}, 2 \mathrm{H}, J_{1}=1.2, J_{2}=8\right), 3.16(\mathrm{~s}, 2 \mathrm{H}) .{ }^{13} \mathrm{C}$ NMR $\left(100 \mathrm{MHz}, \mathrm{CDCl}_{3}\right)$ : $140.4,135.0,130.7,125.7,122.9,118.8,112.1,83.7,77.16$ (one carbon peak merged with $\mathrm{CDCl}_{3}$ peak). HRMS (ESI) calculated for $\left[\mathrm{C}_{16} \mathrm{H}_{8} \mathrm{~S}\right]$ is 232.0347 , Found 232.0352. 
3.0 General procedure for the preparation of bis-triazolyl products 8-10 (GP-2). The corresponding dialkyne $(0.463 \mathrm{mmol})$ and $\mathrm{CuSO}_{4} \cdot 5 \mathrm{H}_{2} \mathrm{O}(11.5 \mathrm{mg}, 0.0463 \mathrm{mmol})$ and sodium ascorbate $(9.12 \mathrm{mg}, 0.0463 \mathrm{mmol})$ were taken in $3: 1{ }^{\mathrm{t}} \mathrm{BuOH} / \mathrm{H}_{2} \mathrm{O}$ solution and then the respective azide $(1.16 \mathrm{mmol})$ was added to it. The mixture was heated for $4 \mathrm{~h}$ at $70{ }^{\circ} \mathrm{C}$ under microwave irradiation. After cooling to room temperature the solvents were concentrated. The crude product was purified by column chromatography $\left(\mathrm{CH}_{2} \mathrm{Cl}_{2} \quad 100 \%\right.$ then $\mathrm{CH}_{2} \mathrm{Cl}_{2} / \mathrm{MeOH}$ 10:1 and then $\mathrm{CH}_{2} \mathrm{Cl}_{2} / \mathrm{MeOH} / \mathrm{NH}_{4} \mathrm{OH}$ 10:1:1).
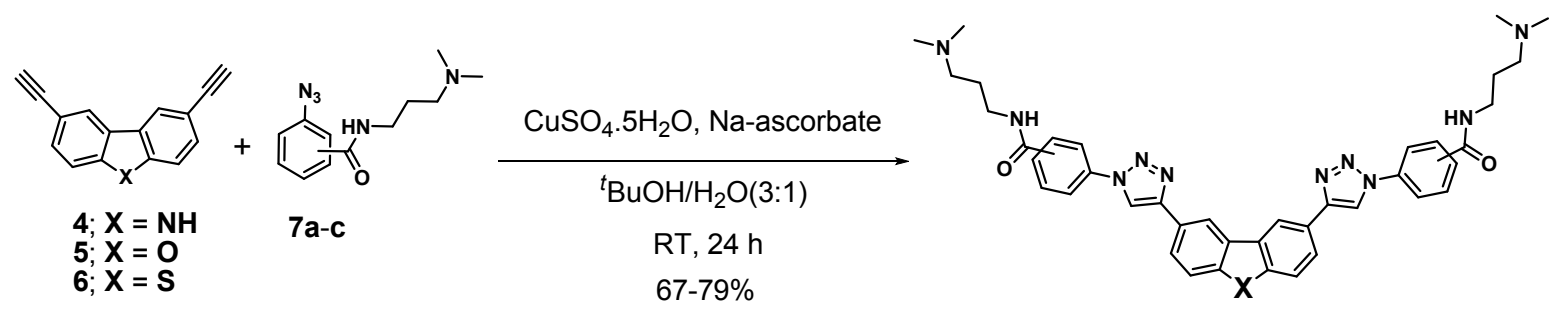

$8 \mathrm{a}-\mathrm{c} ; \mathrm{X}=\mathrm{NH}$

10a-c; $X=S$

Azides used in "Click reaction"

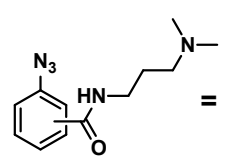

7

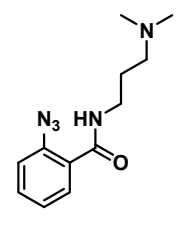

$7 a$

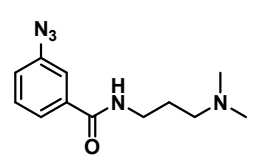

$7 b$

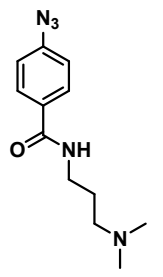

7c

Scheme S2. Synthesis of bis-triazolyl products by $\mathrm{Cu}(\mathrm{I})$ catalysed azide-alkyne cycloaddition.

8a: Following the GP-2, the dialkyne $4(100 \mathrm{mg})$ and azide $7 \mathbf{a}(287 \mathrm{mg})$ afforded $8 \mathbf{a}$ (250 mg, 76\%) as a brown solid. ${ }^{1} \mathrm{H}$ NMR (400 MHz, DMSO-d $\left.{ }^{6}\right): 11.58(\mathrm{~s}, 1 \mathrm{H}), 8.82(\mathrm{~s}, 2 \mathrm{H}), 8.45$ (s, 2H), $8.47(\mathrm{t}, 2 \mathrm{H}, J=5.4), 7.99(\mathrm{~d}, 2 \mathrm{H}, J=9.8), 7.71-7.68(\mathrm{~m}, 4 \mathrm{H}), 7.65-7.62(\mathrm{~m}, 6 \mathrm{H})$, $3.21(\mathrm{~s}, 4 \mathrm{H}), 2.27(\mathrm{~s}, 4 \mathrm{H}), 2.15(\mathrm{~s}, 12 \mathrm{H}), 1.78(\mathrm{~s}, 4 \mathrm{H}) .{ }^{13} \mathrm{C}$ NMR (100 MHz, DMSO-d 6 ): $166.2,153.4,147.6,140.0,134.2,133.3,130.5,129.5,128.8,125.4,122.8,121.5,121.3$, 117.2, 111.6, 55.2, 44.5, 37.1, 26.5. HRMS (ESI) calculated for $\left[\mathrm{C}_{40} \mathrm{H}_{44} \mathrm{~N}_{11} \mathrm{O}_{2}\right]: 710.3679$, Found 710.3631 
8b: Following the GP-2, dialkyne 4 (100 mg) and azide $\mathbf{7 b}(287 \mathrm{mg})$ afforded $\mathbf{8 b}$ (240 mg, 73\%) as a brown solid. ${ }^{1} \mathrm{H}$ NMR (400 MHz, DMSO-d $)$ ) 11.64 (s, 1H), 9.40 (s, 2H), 8.83 (s, $4 \mathrm{H}), 8.15(\mathrm{~d}, 2 \mathrm{H}, J=7.8), 8.06(\mathrm{~d}, 2 \mathrm{H}, J=8.3), 7.97(\mathrm{~d}, 2 \mathrm{H}, J=7.8), 7.75(\mathrm{t}, 2 \mathrm{H}, J=8.3)$, $7.65(\mathrm{~d}, 2 \mathrm{H},, J=8.3), 3.36(\mathrm{t}, 4 \mathrm{H},, J=6.8), 2.38(\mathrm{t}, 4 \mathrm{H},, J=6.8), 2.22(\mathrm{~s}, 12 \mathrm{H}), 1.74(\mathrm{t}, 4 \mathrm{H}$, $J=6.8) .{ }^{13} \mathrm{C}$ NMR (100 MHz, DMSO-d 6 ): 165.0, 153.4, 148.7, 140.2, 136.8, 136.4, 130.1, 127.1, 123.8, 122.9, 122.2, 121.2, 118.6, 117.3, 111.8, 56.7, 45.0, 37.8, 26.7. HRMS (ESI) calculated for $\left[\mathrm{C}_{40} \mathrm{H}_{44} \mathrm{~N}_{11} \mathrm{O}_{2}\right]: 710.3679$, Found 710.3704

8c: Following the GP-2, the dialkyne 4 (100 mg) and azide 7c (287 mg) afforded 8c (241 mg, 73\%) as a yellow solid. ${ }^{1} \mathrm{H}$ NMR (500 MHz, DMSO-d $\left.{ }_{6}\right): 11.61(\mathrm{~s}, 1 \mathrm{H}), 9.42(\mathrm{~s}, 2 \mathrm{H}), 8.81(\mathrm{~s}$, $2 \mathrm{H}), 8.72(\mathrm{~s}, 2 \mathrm{H}), 8.12(\mathrm{~s}, 8 \mathrm{H}), 8.04(\mathrm{~d}, 2 \mathrm{H}, J=8.4), 7.65(\mathrm{~d}, 2 \mathrm{H}, J=8.4), 3.32(4 \mathrm{H}$, merged with water peak), $2.48(\mathrm{~s}, 4 \mathrm{H}), 2.30(\mathrm{~s}, 12 \mathrm{H}), 1.75(\mathrm{t}, 4 \mathrm{H}, J=6.7) ;{ }^{13} \mathrm{C}$ NMR: $(125 \mathrm{MHz}$, DMSO-d $\left.{ }_{6}\right): 165,148.7,140.2,138.4,134.2,128.9,123.8,122.8,121.1,119.3,118.5,117.3$, 111.7, 56.3, 44.4, 37.5, 26.4. HRMS (ESI) calculated for $\left[\mathrm{C}_{40} \mathrm{H}_{44} \mathrm{~N}_{11} \mathrm{O}_{2}\right]$ : 710.3679, Found 710.3740 .

9a: Following the GP-2, the dialkyne $5(100.10 \mathrm{mg})$ and azide $7 \mathbf{a}(287 \mathrm{mg})$ afforded 9a (237 mg, 72\%) as a brown solid. ${ }^{1} \mathrm{H}$ NMR (400 MHz, DMSO-d 6 ): 9.08 (s, 2H), 9.05 (s, 2H), 8.57 (s, 2H), $8.32(\mathrm{~s}, 2 \mathrm{H}), 8.16(\mathrm{~s}, 2 \mathrm{H}), 7.73(\mathrm{~s}, 4 \mathrm{H}), 7.67(\mathrm{~s}, 4 \mathrm{H}, 3.44(\mathrm{t}, 4 \mathrm{H}, J=6.7), 2.44(\mathrm{t}, 4 \mathrm{H}$, $J=6.7), 2.25(\mathrm{~s}, 12 \mathrm{H}), 1.60(\mathrm{t}, 4 \mathrm{H}, J=6.7) .{ }^{13} \mathrm{C}$ NMR (100 MHz, DMSO-d 6 ): 164.8, 153.3, $146.4,138.7,134.1,133.3,130.6,129.7,128.9,127.5,125.4,123.8,123.1,118.7,115.6$, 55.7, 43.8, 37.0, 25.8. HRMS (ESI) calculated for $\left[\mathrm{C}_{40} \mathrm{H}_{43} \mathrm{~N}_{10} \mathrm{O}_{3}\right]$ 711.3520, Found 711.3517. 
9b: Following the GP-2, the dialkyne 5 (100.10 mg) and azide $7 \mathbf{b}(287 \mathrm{mg})$ afforded $\mathbf{9 b}$ (260 mg, $79 \%$ ) as a brown solid. ${ }^{1} \mathrm{H}$ NMR (400 MHz, DMSO-d 6 ): 9.60 (s, 2H), $9.01(\mathrm{~s}, 2 \mathrm{H}), 8.87$ (s, 2H), $8.55(\mathrm{~s}, 2 \mathrm{H}), 8.16(\mathrm{~d}, 4 \mathrm{H}, J=7.0), 8.00(\mathrm{~d}, 2 \mathrm{H}, J=8.0), 7.86(\mathrm{~d}, 2 \mathrm{H}, J=8.5), 7.76-$ $7.72(\mathrm{~m}, 2 \mathrm{H}), 2.84-2.78(\mathrm{~m}, 4 \mathrm{H}), 2.30(\mathrm{~s}, 12 \mathrm{H}), 1.78(\mathrm{t}, 4 \mathrm{H}, J=6.7) .{ }^{13} \mathrm{C} \mathrm{NMR}(100 \mathrm{MHz}$ DMSO- $\left.\mathrm{d}_{6}\right): 165.0,155.8,147.5,136.7,136.2,130.1,127.3,125.8,125.5,124.1,122.2$, $119.8,118.2,112.4,62.6,45.4,37.5,26.2$. HRMS (ESI) calculated for $\left[\mathrm{C}_{40} \mathrm{H}_{43} \mathrm{~N}_{10} \mathrm{O}_{3}\right]$ 711.3520, Found 711.3512.

9c: Following the GP-2, the reaction of the dialkyne 5 with azide $7 \mathbf{c}(287 \mathrm{mg})$ afforded $\mathbf{9 c}$ (246.84 mg, 75\%) as a white powder. ${ }^{1} \mathrm{H}$ NMR (500 MHz, DMSO-d 6 ): $9.51(\mathrm{~s}, 2 \mathrm{H}), 8.84(\mathrm{~s}$, 2H), $8.76(\mathrm{~s}, 2 \mathrm{H}), 8.16-8.12(\mathrm{~m}, 10 \mathrm{H}), 7.91(\mathrm{~d}, 2 \mathrm{H}, J=8.4), 2.59(\mathrm{~s}, 4 \mathrm{H}), 2.38(\mathrm{~s}, 12 \mathrm{H}), 1.78$ (t, $4 \mathrm{H}, J=6.7) .{ }^{13} \mathrm{C}$ NMR (125 MHz, DMSO-d 6 ): 165.1, 155.8, 147.5, 138.3, 134.3, 129.0, $125.7,124.0,119.6,119.4,118.0,115.6,112.5,56.0,44.2,37.3,25.9 . \quad$ HRMS (ESI) calculated for $\left[\mathrm{C}_{40} \mathrm{H}_{43} \mathrm{~N}_{10} \mathrm{O}_{3}\right]$ 711.3520, Found 711.3516.

10a: Following the GP-2, the dialkyne $6(107.6 \mathrm{mg})$ with azide 7a $(287 \mathrm{mg})$ afforded 10a (225.5 mg, 67\%) as a brown solid. ${ }^{1} \mathrm{H}$ NMR (400 MHz, DMSO-d 6 ): 8.92 (s, 2H), 8.80 (s, 2H), $8.47(\mathrm{~s}, 2 \mathrm{H}), 8.14(\mathrm{~d}, 2 \mathrm{H}, J=8.6), 7.85(\mathrm{~d}, 2 \mathrm{H}, J=8.6), 7.72(\mathrm{~s}, 4 \mathrm{H}), 7.66(\mathrm{~s}, 4 \mathrm{H}), 3.14$ (m, 4H), $2.14(\mathrm{~s}, 4 \mathrm{H}), 2.03(\mathrm{~s}, 12 \mathrm{H}), 1.51(\mathrm{t}, 4 \mathrm{H}, J=7.3) .{ }^{13} \mathrm{C}$ NMR (100 MHz, DMSO-d 6 ): $166.0,155.7,146.4,134.1,133.4,130.5,129.6,128.8,126.0,125.4,124.1,122.5,118.0$, 112.3, 56.5, 44.9, 37.3, 26.7. HRMS (ESI) calculated for $\left[\mathrm{C}_{40} \mathrm{H}_{43} \mathrm{~N}_{10} \mathrm{O}_{2} \mathrm{~S}\right]$ : 727.3291, Found 727.3288 .

10b: Following the GP-2, the dialkyne $6(107.6 \mathrm{mg})$ and azide $7 \mathbf{b}(287 \mathrm{mg})$ afforded $\mathbf{1 0 b}$ (239 mg, 71\%) as a brown solid. ${ }^{1} \mathrm{H}$ NMR (500 MHz, DMSO-d 6 ): 9.58 (s, 2H), 9.08 (s, 2H), $8.80(\mathrm{~s}, 2 \mathrm{H}), 8.46(\mathrm{~s}, 2 \mathrm{H}), 8.19(\mathrm{~s}, 6 \mathrm{H}), 7.99(\mathrm{~s}, 2 \mathrm{H}), 7.79(\mathrm{~s}, 2 \mathrm{H}), 3.35$ (4H, merged with water peak), $2.30(\mathrm{t}, 2 \mathrm{H}, J=9.2), 1.71(\mathrm{t}, 2 \mathrm{H},, J=8.55) ;{ }^{13} \mathrm{C}$ NMR (100 MHz, DMSO-d 6 ): 
$165.0,153.3,147.5,138.9,136.7,136.3,135.4,130.1,127.2,124.7,123.9,122.4,120.0$, 118.9, 118.6, 56.5, 44.6, 37.7, 26.4. HRMS (ESI) calculated for $\left[\mathrm{C}_{40} \mathrm{H}_{43} \mathrm{~N}_{10} \mathrm{O}_{2} \mathrm{~S}\right]:$ 727.3291, Found 727.3287.

10c: Following the GP-2, the dialkyne $6(107.6 \mathrm{mg})$ and azide $7 \mathbf{c}(287 \mathrm{mg})$ afforded 10c (245.7 mg, 73\%) as a white solid. ${ }^{1} \mathrm{H}$ NMR (500 MHz, DMSO-d 6 ): 9.60 (s, 2H), 9.05 (s, 2H), $8.74(\mathrm{~s}, 2 \mathrm{H}), 8.21(\mathrm{~d}, 2 \mathrm{H}, J=8), 8.16-8.12(\mathrm{~m}, 10 \mathrm{H}), 3.35(4 \mathrm{H}$, merged with water peak), $2.48(\mathrm{~s}, 4 \mathrm{H}), 2.30(12 \mathrm{H}, \mathrm{s}), 1.75(\mathrm{t}, 4 \mathrm{H}, J=7.4) .{ }^{13} \mathrm{C}$ NMR (100 MHz, DMSO-d 6 ): 165.1, $147.5,139.0,138.3,135.4,134.4,129.0,127.1,124.7,123.9,119.9,119.5,118.6,56.4,44.5$, 37.5, 26.4. HRMS (ESI) calculated for $\left[\mathrm{C}_{40} \mathrm{H}_{43} \mathrm{~N}_{10} \mathrm{O}_{3}\right]$ 727.3291, Found 727.3295.
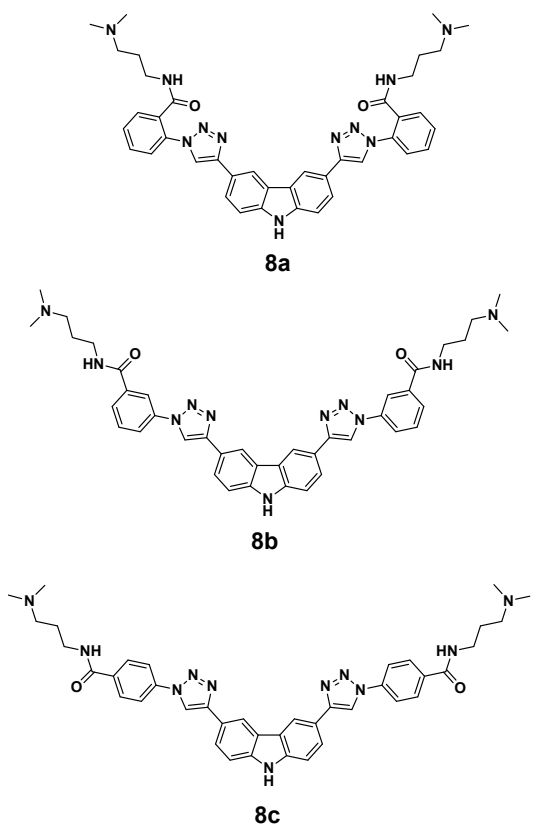
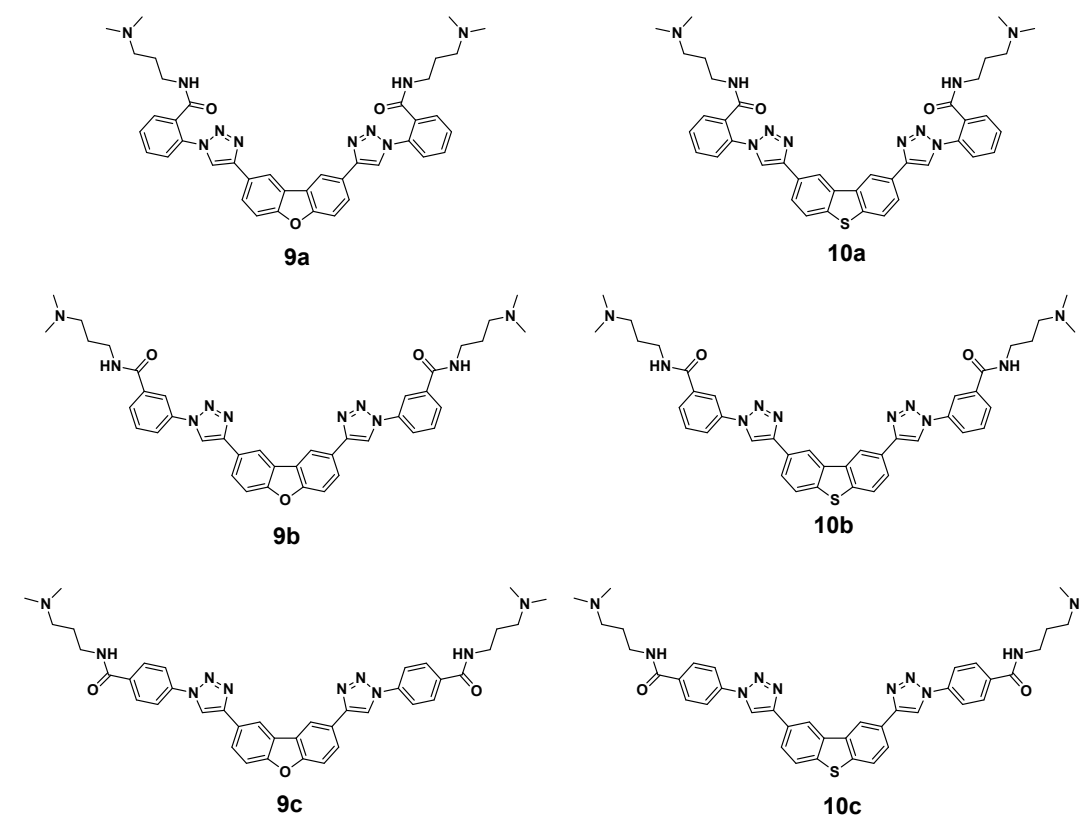

9c

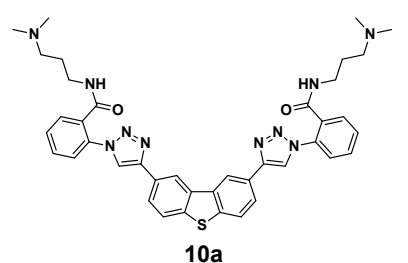

$10 \mathrm{~b}$

Figure S1. Bis-triazolyl carbazole, dibenzofuran and dibenzothiophene derivatives. 
4.0 HPLC chromatograms of the ligands released by DNA-AuMNps.

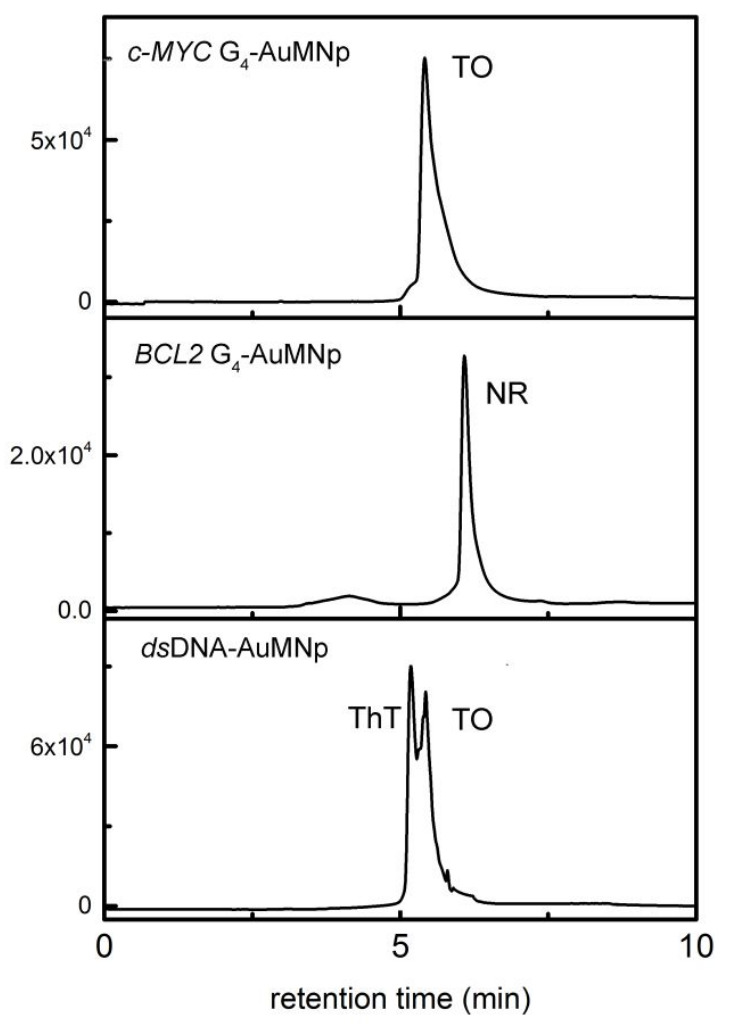

Figure S2. HPLC chromatograms of the ligands released from $c-M Y C \mathrm{G}_{4}, B C L 2 \mathrm{G}_{4}$ and $d s$ DNA-AuMNps from the mixture comprising of TO, ThT, MTX and NR. 


\subsection{ESI-MS spectra of compounds isolated from $G_{4}-A u M N p$ and dsDNA-AuMNps.}
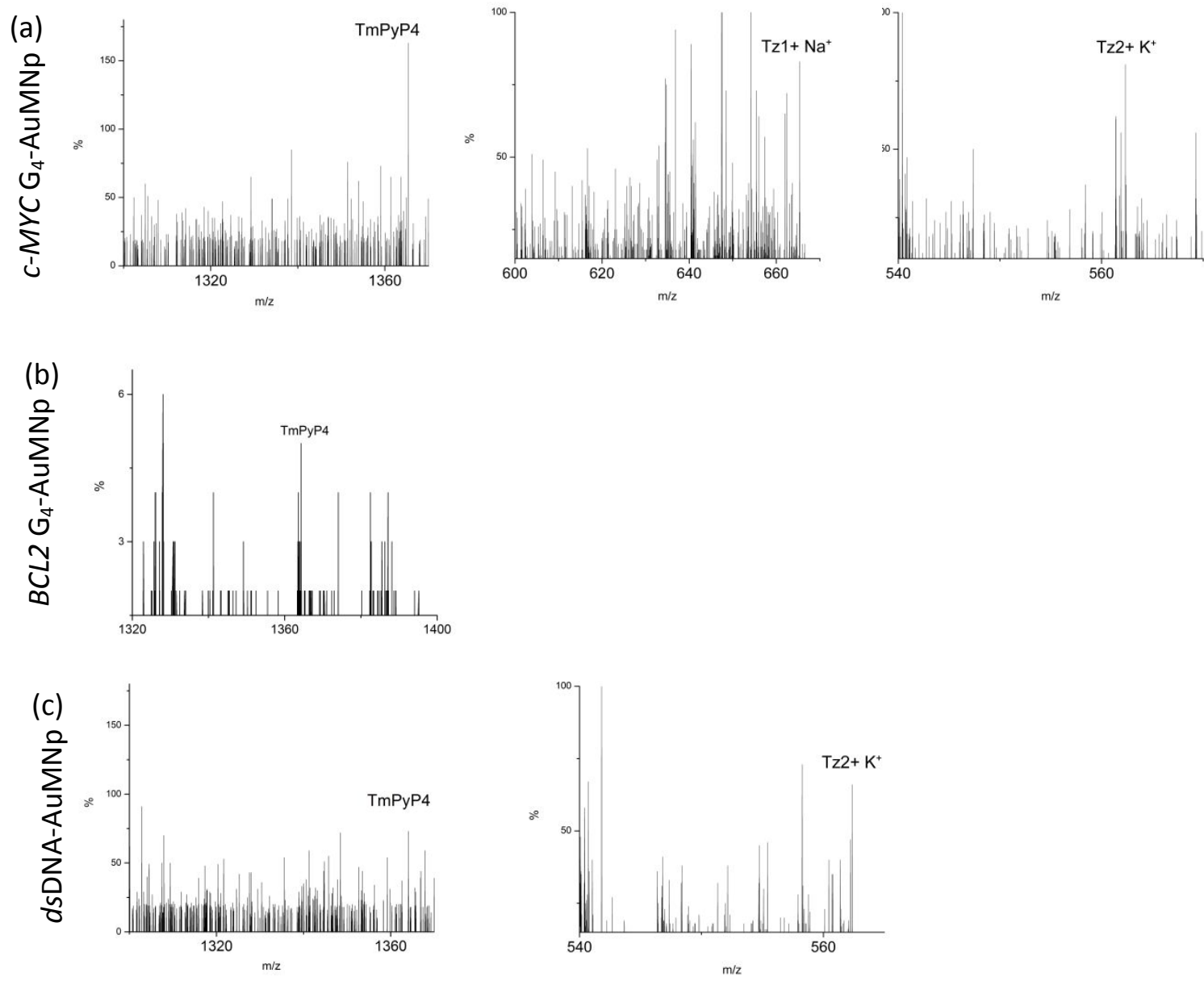

Figure S3. ESI-MS analysis of the HPLC fractions of known ligands isolated from $c-M Y C \mathrm{G}_{4^{-}}$ AuMNps, BCL2 $\mathrm{G}_{4}$-AuMNps and dsDNA-AuMNps. (a) TmPyP4, Tz1 and Tz2 captured by c-MYC $\mathrm{G}_{4}$-AuMNps. (b) TmPyP4 exclusively captured by BCL2 $\mathrm{G}_{4}$-AuMNps and (c) TmPyP4 and Tz2 captured by dsDNA-AuMNps. 


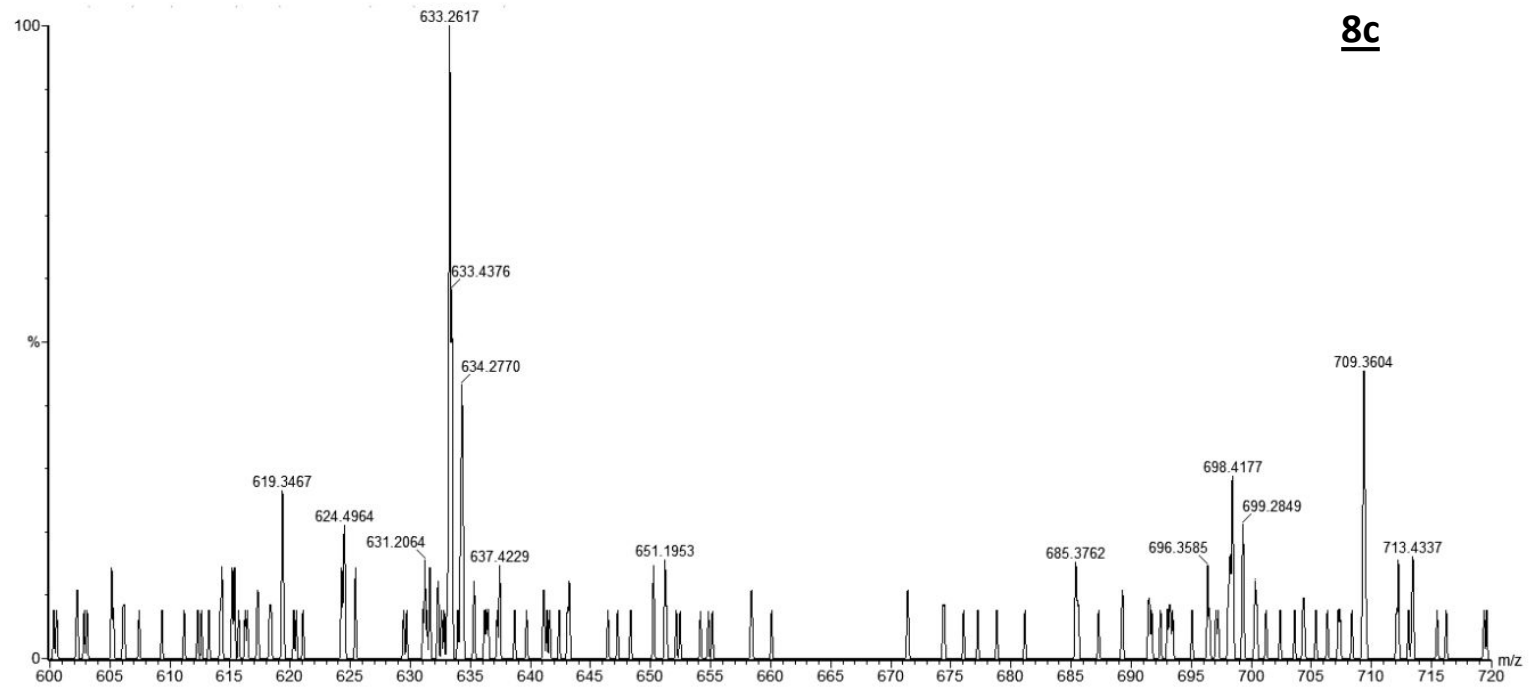

Figure S4. ESI-MS analysis of the captured ligand $\mathbf{8 c}$ by $B C L 2 \mathrm{G}_{4}-\mathrm{AuMNps}$.

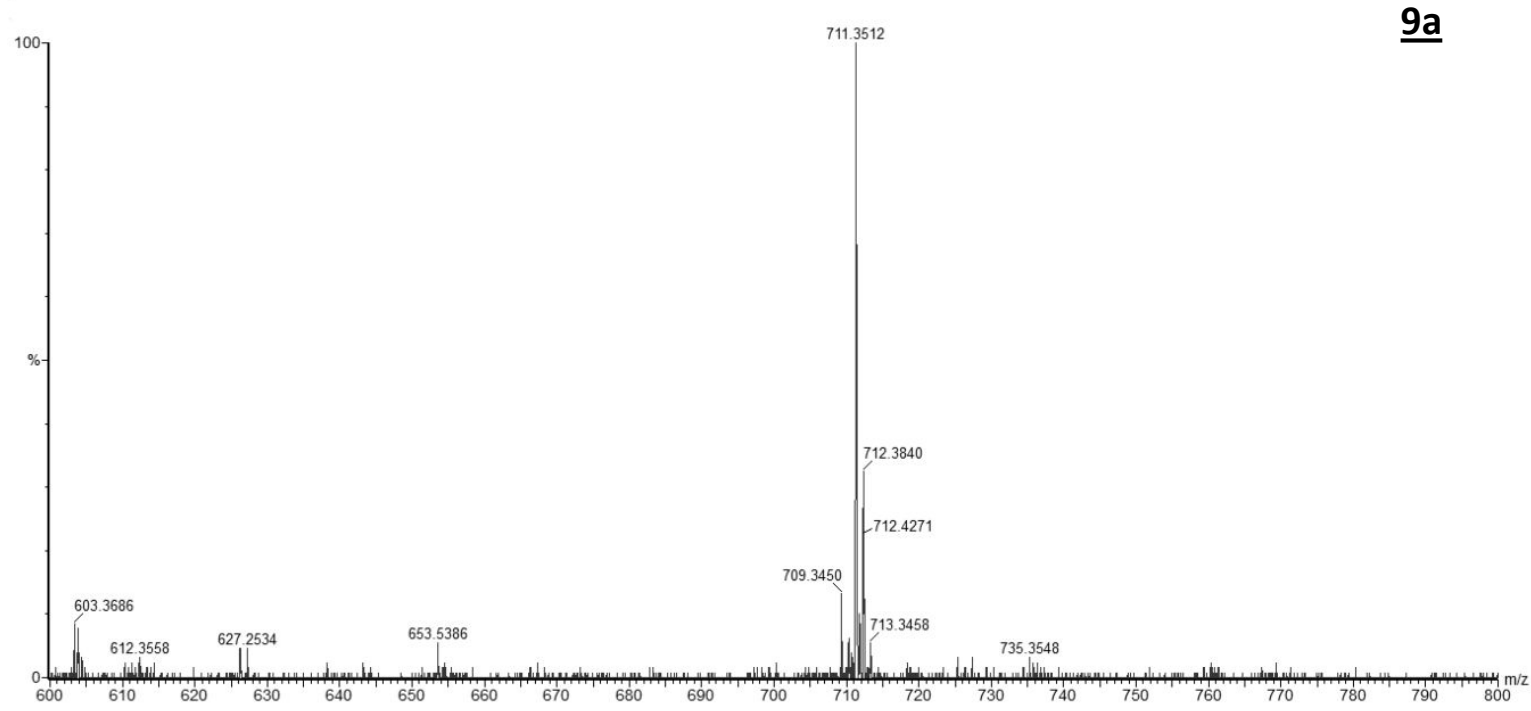

Figure S5. ESI-MS analysis of the captured ligand 9a by $c-M Y C \mathrm{G}_{4}-\mathrm{AuMNps}$. 
6.0 Fluorescence spectroscopic titration. The fluorescence experiments were carried out using a Horiba Jobin Yvon Fluorolog-3 instrument at $25{ }^{\circ} \mathrm{C}$ in a thermostated cell holder using quartz cuvette of $1 \mathrm{~cm}$ path-length. For fluorescence titration pre-annealed Gquadruplexes, $d s \mathrm{DNA}$ and $s c r \mathrm{DNA}$ were used and titrations were performed in $100 \mathrm{mM}$ Tris. $\mathrm{KCl}$ buffer $(\mathrm{pH}$ 7.4). Ligand concentration is $1 \mu \mathrm{M}$. The spectral data represents the mean of three scans and the final analysis of the data was carried out using Origin 8 .
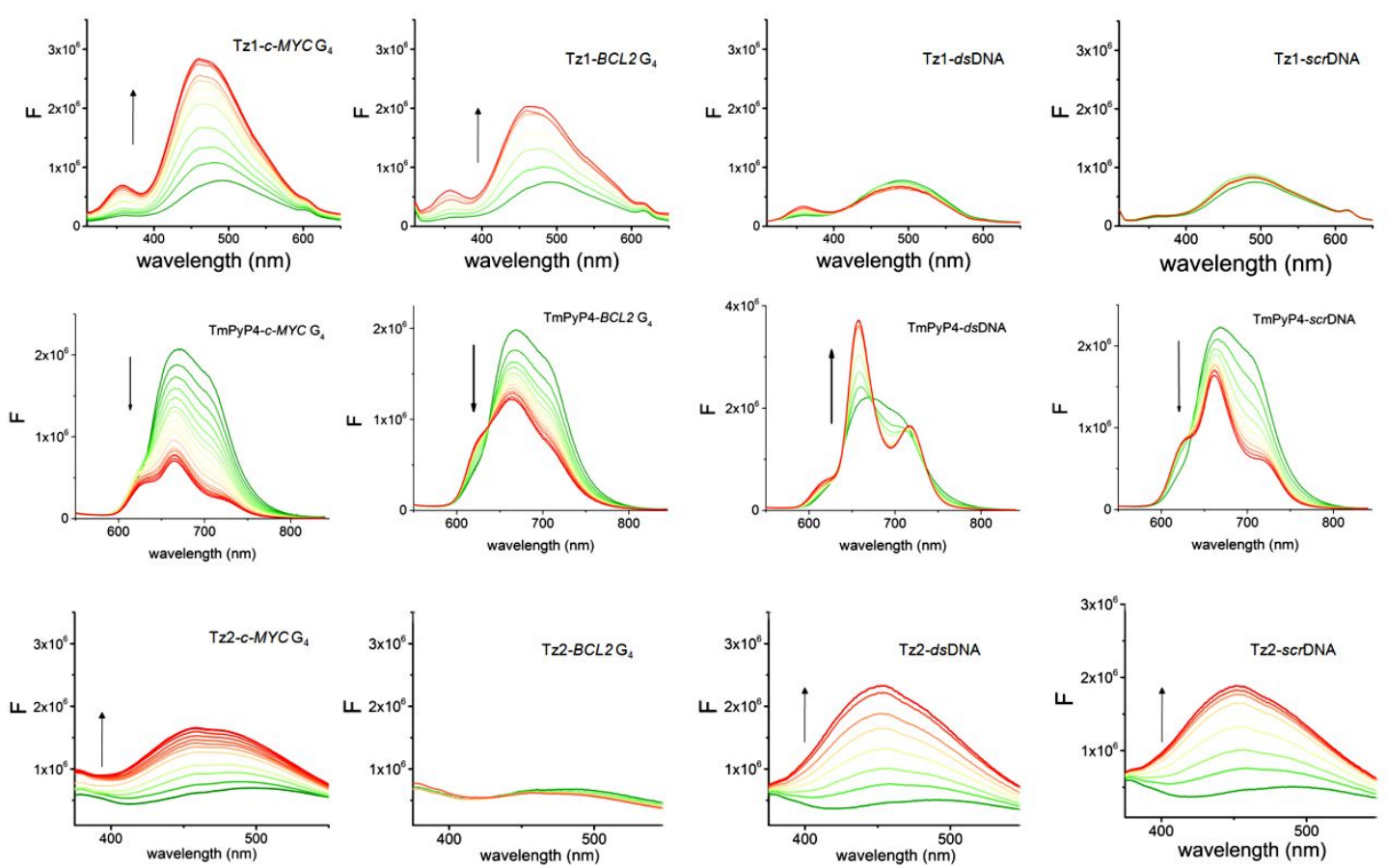

Figure S6. Fluorescence responses of Tz1, TmPyP4 and Tz2 $(1 \mu \mathrm{M})$ with incremental addition of $c-M Y C$ and $B C L 2 \mathrm{G}_{4}, d s \mathrm{DNA}$ and $s c r$ DNA in $100 \mathrm{mM}$ Tris-KCl buffer, pH 7.4. (Compound Tz1: $\lambda_{e x}=280 \mathrm{~nm}$; TmPyP4: $\lambda_{e x}=430 \mathrm{~nm}$ and Tz2: $\lambda_{e x}=285 \mathrm{~nm}$ )

The recorded spectral data was used to determine the dissociation constant of the ligands for quadruplexes using the following formula (1):

$$
\mathrm{F}=\mathrm{F}_{0}+\frac{\left(\mathrm{F}_{\max }-\mathrm{F}_{0}\right)[\mathrm{DNA}]}{\mathrm{K}_{d}^{\mathrm{app}}+[\mathrm{DNA}]}
$$

$\mathrm{F}$ is the fluorescence intensity, $\mathrm{F}_{\max }$ is the maximum fluorescence intensity, $\mathrm{F}_{0}$ is the fluorescence intensity in the absence of DNA and $\mathrm{K}_{d}^{\text {app }}$ is the apparent dissociation constant. 


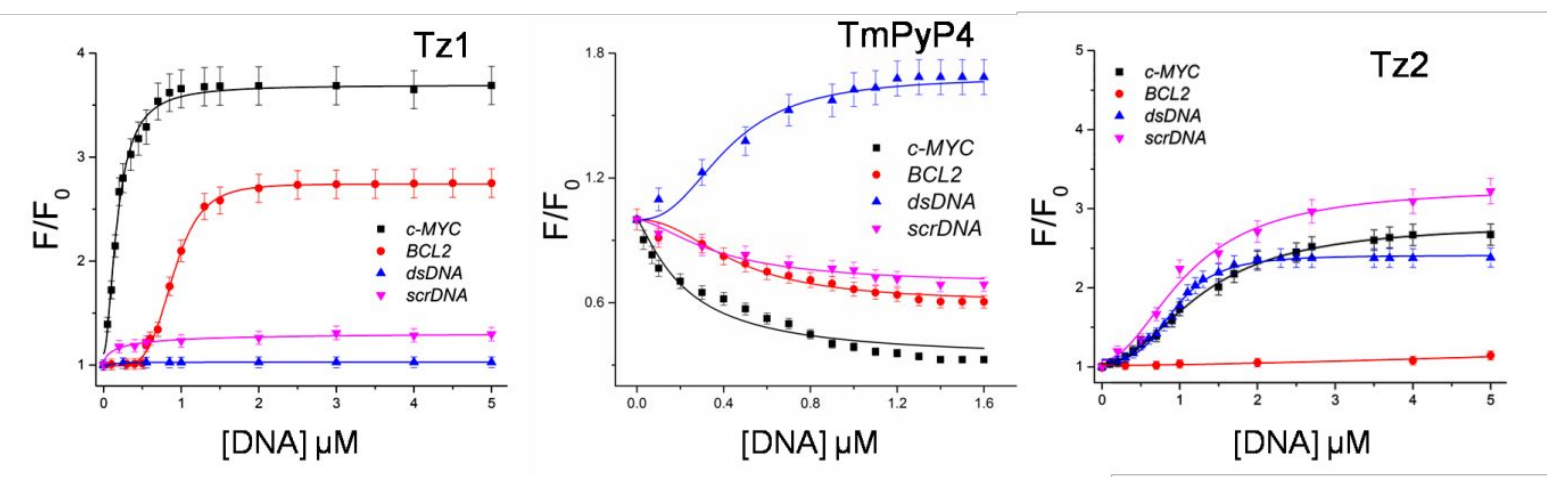

Figure S7. Fluorescence response curves of Tz1, TmPyP4 and Tz2. 
7.0 FRET melting analysis. FRET melting assay was carried out on a real-time PCR apparatus (Roche LightCycler ${ }^{\circledR} 480$ II). All DNA sequences were dual labeled with a donor fluorophore 6- carboxyfluorescein $\left(5^{\prime}\right.$-FAM) and an acceptor fluorophore 6carboxytetramethylrhodamine (3'- TAMRA). FRET experiments were performed with a 200 $\mathrm{nM}$ oligonucleotide concentration in $60 \mathrm{mM}$ potassium cacodylate buffer, $\mathrm{pH}$ 7.4. All HPLC purified dual labeled DNA oligonucleotides were purchased from SIGMA-Aldrich. 5'-FAM and 3'-TAMRA-labeled DNA was annealed at a concentration of $400 \mathrm{nM}$ by heating at $95{ }^{\circ} \mathrm{C}$ for $5 \mathrm{~min}$ followed by gradual cooling to room temperature at a controlled rate of $0.1{ }^{\circ} \mathrm{C} / \mathrm{min}$. Titration experiments were performed by adding different concentration of triazole products separately to $200 \mathrm{nM}$ solution of dual labeled DNA oligonucleotides in $60 \mathrm{mM}$ potassium cacodylate buffer $(\mathrm{pH}$ 7.4). Fluorescence measurements were taken with an excitation wavelength of $483 \mathrm{~nm}$ and a detection wavelength of $533 \mathrm{~nm}$ at intervals of $1^{\circ} \mathrm{C}$ over the range of $37-95^{\circ} \mathrm{C}$. Melting temperatures were calculated using Origin Pro 8 data analysis. Experiments were performed in triplicates and an average value of $\Delta \mathrm{T}_{\mathrm{m}}$ are represented.

Dual fluorescently labeled DNA oligonucleotides used in these experiments are as follows:

\begin{tabular}{|c|c|c|}
\hline DNA & Sequence & $\mathrm{T}_{\mathrm{m}}\left({ }^{\circ} \mathrm{C}\right)$ \\
\hline$c-M Y C$ & $5^{\prime \prime} \mathrm{FAM}-\mathrm{d}\left(\mathrm{TGAG}_{3} \mathrm{TG}_{3} \mathrm{TAG}_{3} \mathrm{TG}_{3} \mathrm{TA}_{2}\right)$-TAMRA 3' & 70.9 \\
\hline BCL2 & 5'-FAM-d $\left(\mathrm{AG}_{4} \mathrm{CG}_{3} \mathrm{CGCG}_{3} \mathrm{AG}_{2} \mathrm{~A}_{2} \mathrm{G}_{5} \mathrm{CG}_{3} \mathrm{AGCG}_{4} \mathrm{CTG}\right)-\mathrm{TAMRA} 3^{\prime}$ & 77.1 \\
\hline$K R A S$ & 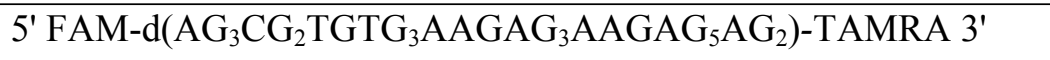 & 50.9 \\
\hline$c-K I T$ & 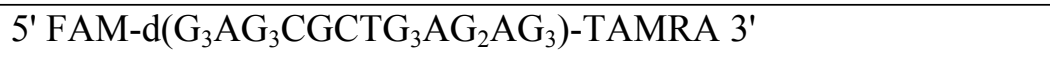 & 60.9 \\
\hline$d s D N A$ & $5^{\prime}$ FAM-d( $\left.\mathrm{CA}_{5} \mathrm{~T}_{5} \mathrm{GCAT}_{5} \mathrm{G}\right)-\mathrm{TAMRA} 3^{\prime}$ & 61.2 \\
\hline
\end{tabular}



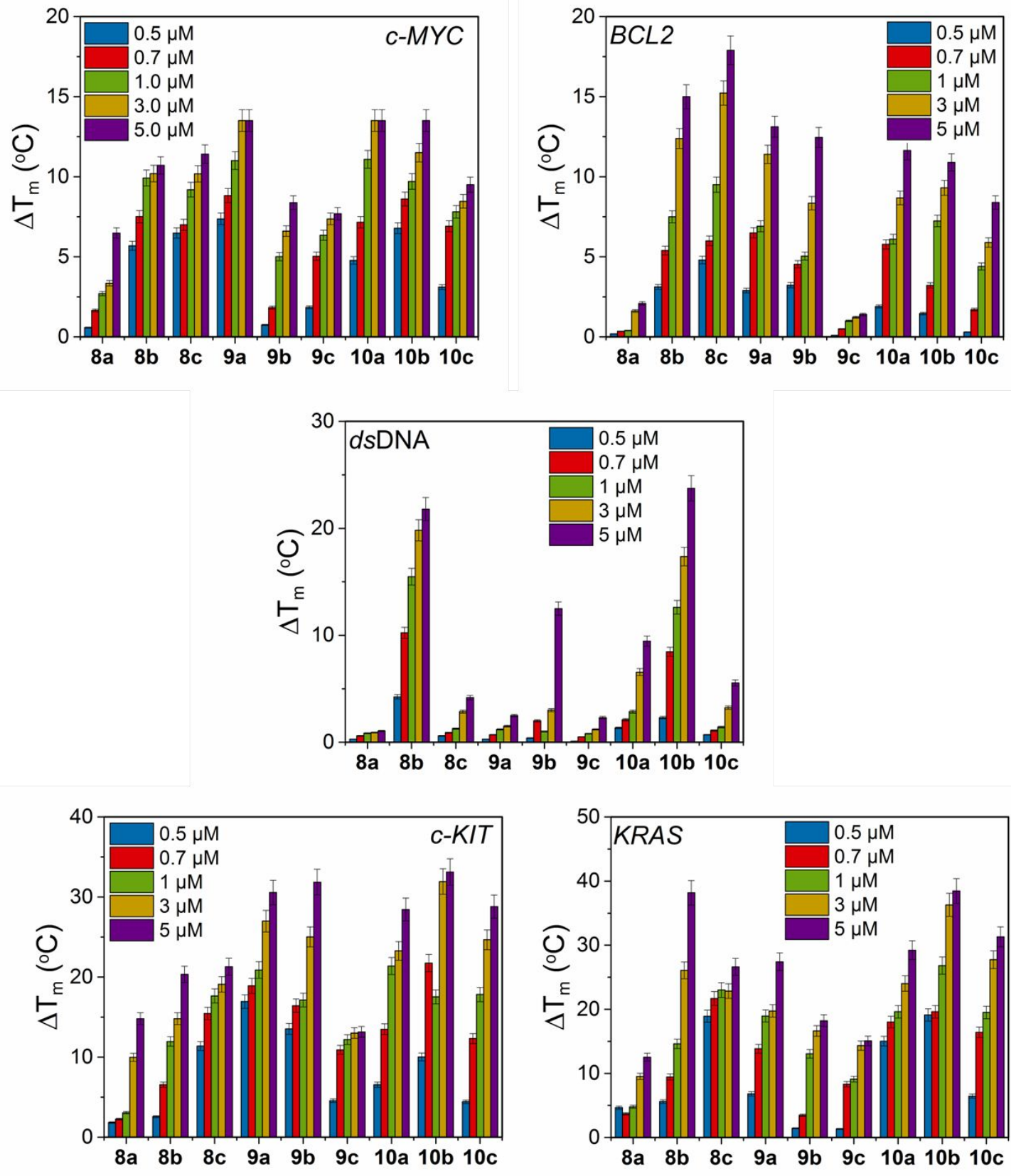

Figure S8. Changes in stabilization temperatures $\left(\Delta \mathrm{T}_{\mathrm{m}}\right)$ of $0.2 \mu \mathrm{M}$ dual labelled Gquadruplex and duplex DNA sequences in Tris. $\mathrm{KCl}$ buffer $(100 \mathrm{mM}, \mathrm{pH} 7.4)$ in the presence different concentrations $(0-5 \mu \mathrm{M})$ of ligands (8-10a-c). 
8.0 Fluorescent intercalator displacement (FID) assay. Pre-folded DNA target $(0.25 \mu \mathrm{M})$ was mixed with thiazole orange, TO $(0.50 \mu \mathrm{M})$ in Tris. $\mathrm{KCl}$ buffer $(100 \mathrm{mM}, \mathrm{pH} 7.4)$ in a total volume of $0.5 \mathrm{~mL}$ and incubated for $30 \mathrm{~min}$ at $\mathrm{rt}$. Fluorescence spectrum was recorded after addition of each compound followed by a 3 min equilibration period. The percentage of TO displacement was calculated from the fluorescence area $\left(\mathrm{F}_{\mathrm{A}}, 510-750 \mathrm{~nm}\right.$; excitation, 501 $\mathrm{nm}$ ) of the spectra using following equation;

$\%$ of TO displacement $=100-\left[\mathrm{FA} \times 100 / \mathrm{FA}_{0}\right]$

FA is the fluorescence area of TO/DNA complex and $\mathrm{FA}_{0}$ is the fluorescence area from TO bound to the DNA in absence of any ligand. The $\mathrm{DC}_{50}$ values were calculated from the plot of percentage of TO displacement vs the concentration of the ligands.

DNA sequences used in these experiments are:

\begin{tabular}{|l|l|}
\hline DNA & Sequence \\
\hline$c-M Y C$ & $5^{\prime}-\mathrm{d}\left(\mathrm{TGAG}_{3} \mathrm{TG}_{3} \mathrm{TAG}_{3} \mathrm{TG}_{3} \mathrm{TA}_{2}\right)-3^{\prime}$ \\
\hline$B C L 2$ & $5^{\prime}-\mathrm{d}\left(\mathrm{AG}_{4} \mathrm{CG}_{3} \mathrm{CGCG}_{3} \mathrm{AG}_{2} \mathrm{~A}_{2} \mathrm{G}_{5} \mathrm{CG}_{3} \mathrm{AGCG}_{4} \mathrm{CTG}\right)-3^{\prime}$ \\
\hline KRAS & $5^{\prime}-\mathrm{d}\left(\mathrm{AG}_{3} \mathrm{CG}_{2} \mathrm{TGTG}_{3} \mathrm{AAGAG}_{3} \mathrm{AAGAG}_{5} \mathrm{AG}_{2}\right)-3^{\prime}$ \\
\hline$c-K I T$ & $5^{\prime}-\mathrm{d}\left(\mathrm{G}_{3} \mathrm{AG}_{3} \mathrm{CGCTG}_{3} \mathrm{AG}_{2} \mathrm{AG}_{3}\right)-3^{\prime}$ \\
\hline$d S D N A$ & $5^{\prime}-\mathrm{d}\left(\mathrm{CA}_{5} \mathrm{~T}_{5} \mathrm{GCAT}_{5} \mathrm{G}\right)-3^{\prime}$ \\
\hline
\end{tabular}



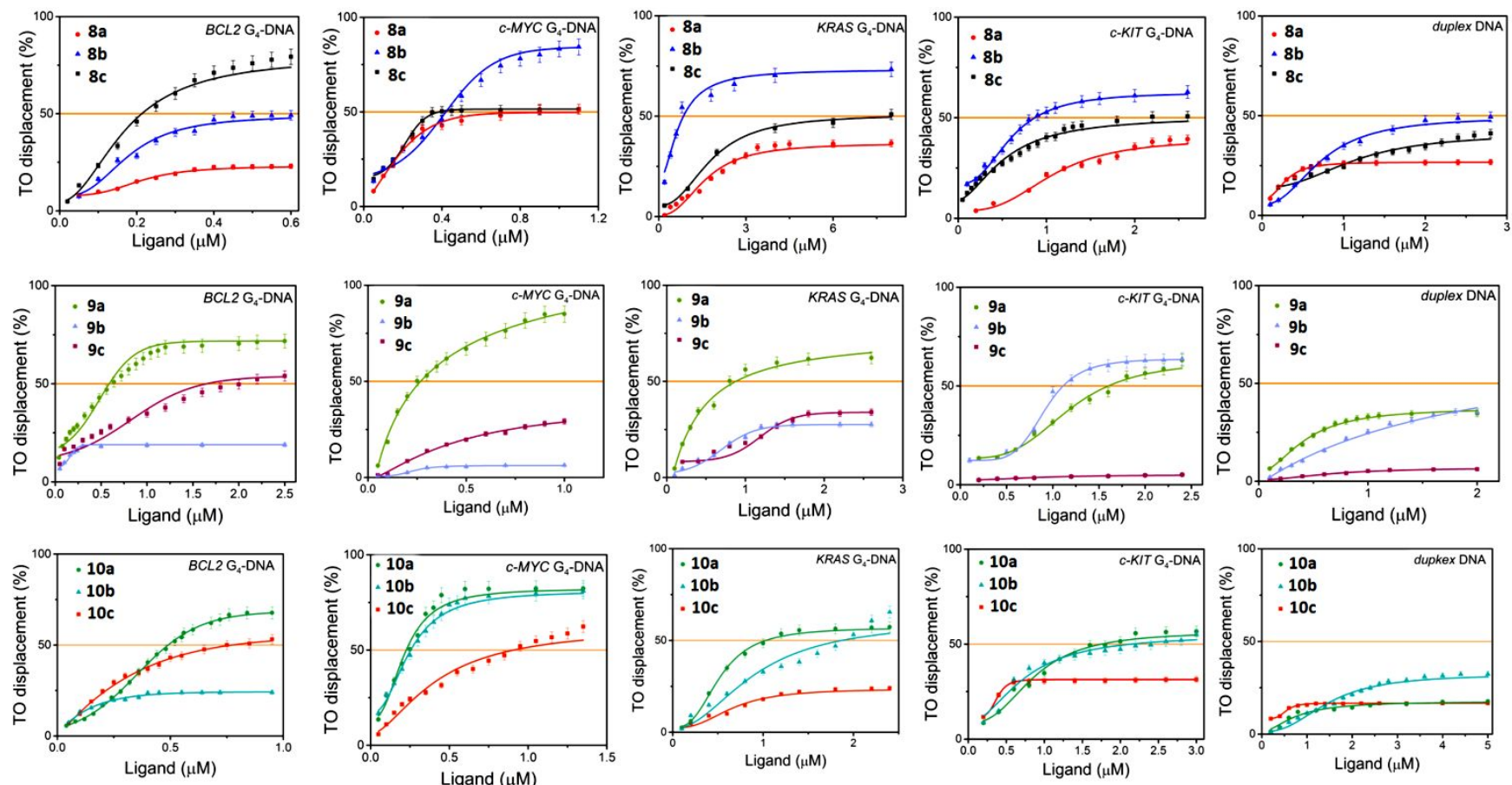

Figure S9. FID curves for the triazole ligands with $\mathrm{G}_{4}$-DNAs and duplex DNAs.

9.0 Cell culture conditions. Human A549 cells were grown in Ham's F12K supplemented with $10 \%$ FBS and $1 \%$ anti-anti. NKE (human normal kidney epithelium cell line) were grown in 10\% FBS supplemented RPMI 1640 media. Cells were maintained in tissue culture flasks at $37^{\circ} \mathrm{C}$ in an atmosphere of $5 \% \mathrm{CO}_{2}$.

10.0 XTT cell viability assay. Viability assays were performed in triplicate on 96-well plates at designated doses. Cells were grown at a density of $10^{4}-10^{5}$ cells/well in $100 \mu \mathrm{L}$ of culture medium and treated with increasing concentrations of the compounds and incubated for $24 \mathrm{~h}$. The XTT/PMS reagent was prepared by mixing $4 \mathrm{mg}$ of XTT in $4 \mathrm{~mL}$ of culture medium followed by the addition of $10 \mu \mathrm{L}$ of $10 \mathrm{mM}$ PMS solution (in PBS). $25 \mu \mathrm{L}$ of this freshly prepared reagent mixture was then directly added to each well containing $100 \mu \mathrm{L}$ of culture media and incubated for $2 \mathrm{~h}$ at $37^{\circ} \mathrm{C}$. The absorbance of XTT formazan was read at $450 \mathrm{~nm}$ on Multiskan FC microplate spectrophotometer (Thermo Scientific). Percentage cell viability was calculated by using the following equation: 


$$
\text { Viable cells }(\%)=\frac{\text { OD of treated cells }}{\text { OD of untreated cells }} X 100
$$

11.0 Flow cytometric assay for apoptosis detection. A549 cells were seeded at a density of $1 \times 10^{6}$ cells $/ \mathrm{mL}$ in each well of a six-well plate and allowed to grow overnight. Cells were treated with the compounds for $24 \mathrm{~h}$. Untreated cells were considered as the positive control. The cells were trypsinized, repeatedly washed with cold PBS and centrifuged at 3000 RPM for $5 \mathrm{~min}$. Cell pellets were then resuspended in $350 \mu \mathrm{L}$ of $1 \mathrm{X}$ Annexin-V binding buffer (0.01M HEPES, $\mathrm{pH} 7.4,0.14 \mathrm{M} \mathrm{NaCl}, 2.5 \mathrm{mM} \mathrm{CaCl}_{2}$ ) and treated with $5 \mu \mathrm{L}$ Annexin V-FITC and $2 \mu \mathrm{L}$ propidium iodide $(1 \mathrm{mg} / \mathrm{mL})$. After incubation for $5 \mathrm{~min}$, each sample was analysed immediately using fluorescence-activated cell sorting (FACS) analysis (BD Biosciences, Mountain View, CA, USA). Approximately 10,000 cells were detected for each sample.

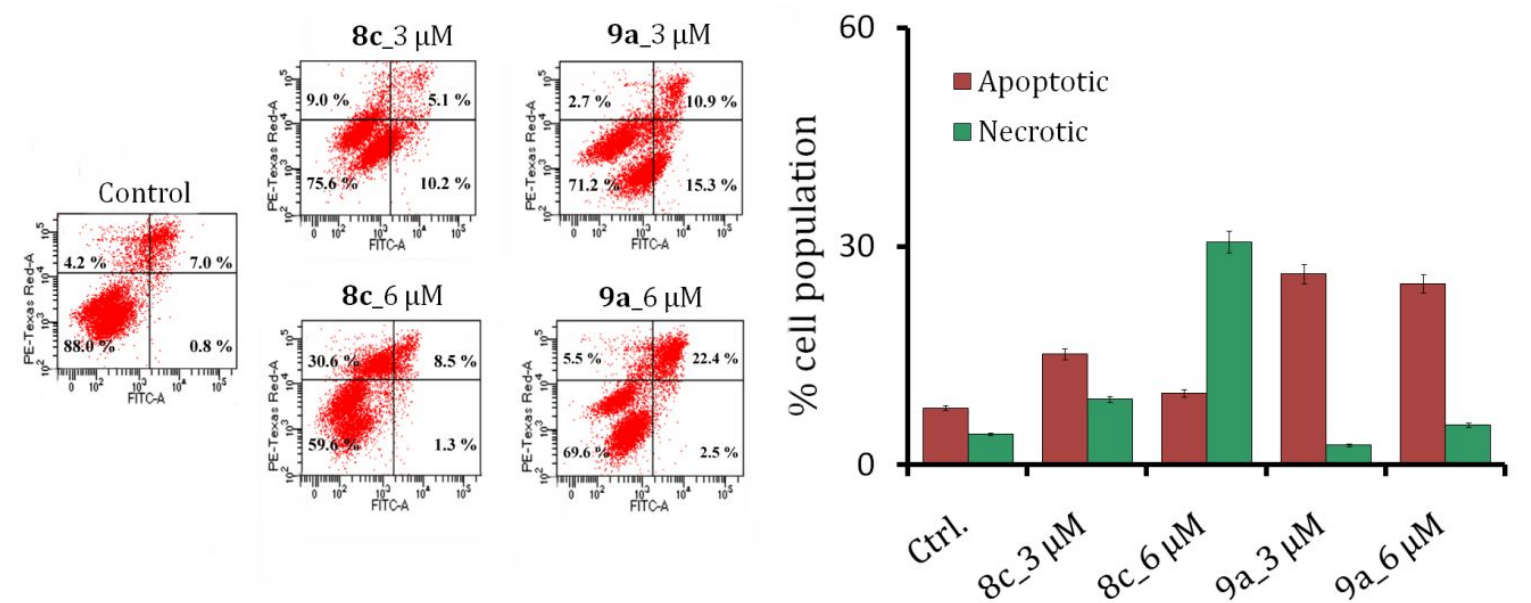

Figure S10. Flow cytometric analysis of A549 cells treated with 8c and 9a for $24 \mathrm{~h}$ determined by Annexin V-FITC and PI staining. Graphical illustration shows percentage of cells in apoptotic and necrotic quadrant. 
12.0 Cell cycle analysis. Cells were seeded in six-well plates at a density of $1 \times 10^{6}$ cells per well and allowed to grow for $24 \mathrm{~h}$. Cells were then treated with ligands for $24 \mathrm{~h}$ in fresh growth medium. Then, cells were washed by PBS, trypsinized, and collected by centrifugation at 3000 RPM, washed once with cold PBS. Cells were then fixed with $2 \mathrm{~mL}$ ice-cold $70 \%$ ethanol, incubated overnight at $4{ }^{\circ} \mathrm{C}$, pelleted and washed with PBS. Then the cells were resuspended in $350 \mu \mathrm{L}$ PBS containing $0.5 \mu \mathrm{g} / \mathrm{mL}$ RNase A (Invitrogen) and incubated at $37^{\circ} \mathrm{C}$ for $30 \mathrm{~min}$ and then $5 \mu \mathrm{L}$ of $1 \mathrm{mg} / \mathrm{mL}$ propidium iodide (PI) was added to each tube. Cell distribution among cell cycle phases were collected on flow cytometer (BD Biosciences). A total of 10,000 events were recorded and cell distribution among cell cycle phases were evaluated using Cell-Quest Pro software (BD).
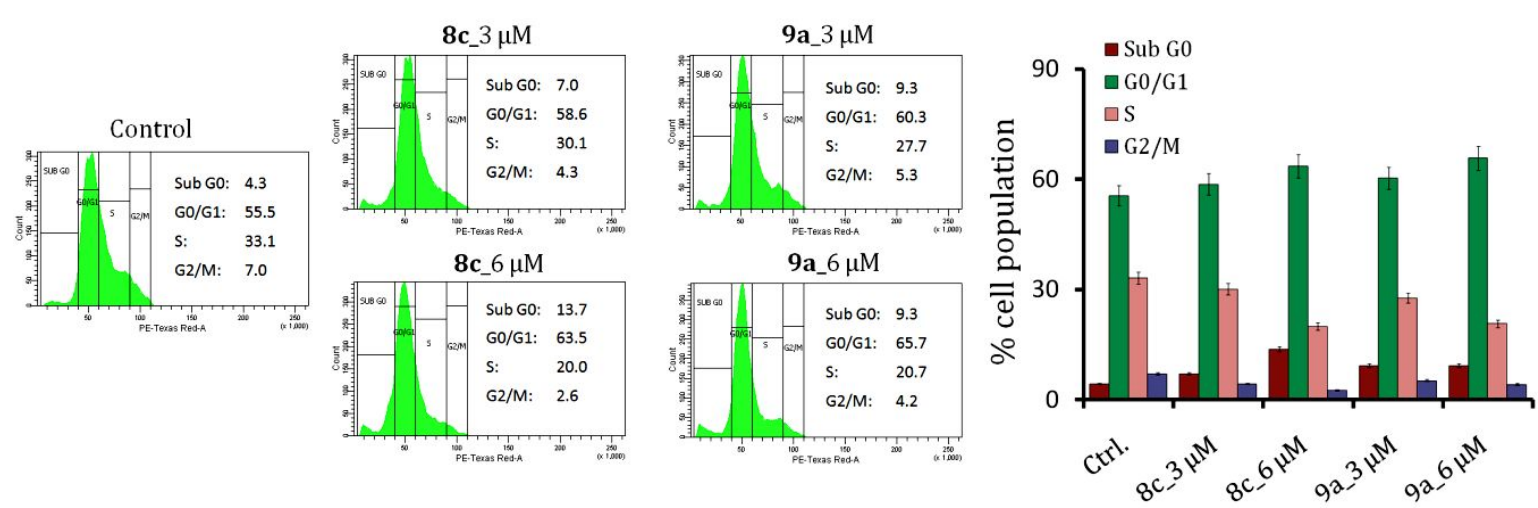

Figure S11. Flow cytometric analysis of A549 cells treated with 8c and 9a for $24 \mathrm{~h}$ determined by PI staining. Graphical illustration shows percentage of cells in different cell cycle phases. 
13.0 Dual luciferase reporter assay. A549 cells were cultured in Ham's F12K supplemented with $10 \%$ FBS and $1 \%$ anti-anti overnight at $37{ }^{\circ} \mathrm{C}, 5 \% \mathrm{CO}_{2}$. Cells were transfected with $0.2 \mu \mathrm{g}$ of $c-M Y C$ Del4 plasmid construct (Addgene plasmid \# 16604-Del4) and $0.5 \mu \mathrm{g}$ of $B C L 2$ promoter construct (Addgene plasmid \# 15381-LB322) using Lipofectamine 2000 (Invitrogen). A Renilla luciferase plasmid, pRL-TK (0.030 $\mu \mathrm{g})$ was cotransfected with each construct for normalization. Transfection was performed in serumfree medium, which was replaced by complete media after $7 \mathrm{~h}$ incubation at $37^{\circ} \mathrm{C}, 5 \% \mathrm{CO}_{2}$. After $36 \mathrm{~h}$ incubation with ligands, cells were washed with PBS and lysed with passive lysis buffer. The levels of firefly and Renilla luciferase luminescence were measured using the Promega Dual Luciferase assay system according to the manufacturer's protocol using Promega GloMax luminometer. Luciferase activities were expressed as relative luciferase units (RLUs) by normalizing to the Renilla expression. Each transfection experiment was run in duplicates. 
14.0 Molecular docking. The structure of the $c-M Y C$ G-quadruplex DNA (PDB ID: 2L7V) and BCL2 G-quadruplex DNA (PDB ID: 2F8U) were procured from RCSB-Protein Data Bank and prepared for docking. The structure of the tentative ligands were initially prepared using ChemDraw package and further energy minimized using Gaussian $09^{1}$ (B3LYP/6-31G* level). Docking calculations were performed in AutoDock4.2 2 using the Lamarckian genetic algorithm ${ }^{3}$ local search method. The AutoDock tools were used to merge nonpolar hydrogens and assign rotatable bonds to the ligands. The grid box was centered on the G-quadruplex DNA with a grid size enough to encompass the full Gqudruplex structure using AutoGrid with a grid spacing of $0.375 \AA$. For both the ligands, 200 independent dockings were carried out. The conformation corresponding to the most cluster members and the lowest binding free energy was selected as the most probable binding conformation.

(a)

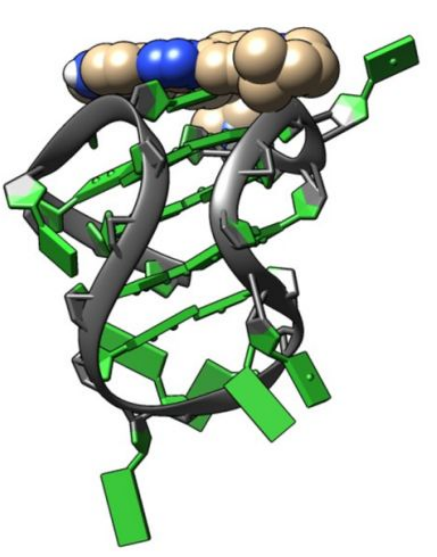

$B C L 2 \mathrm{G}_{4}$ DNA (PDB ID: 2F8U):8c (b)

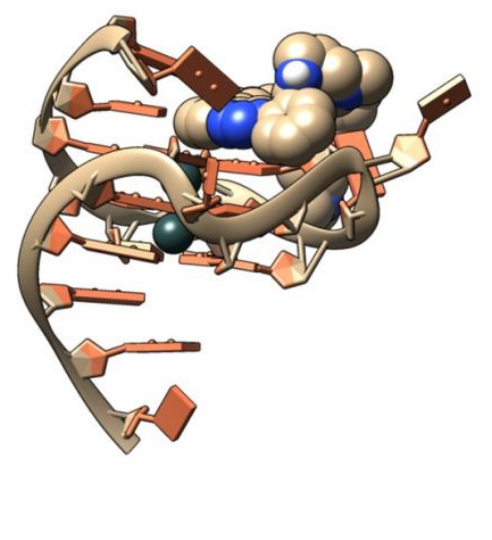

$c-M Y C \mathrm{G}_{4}$ DNA (PDB ID: 2L7V):9a

Figure S12: Molecular docking images of $\mathrm{G}_{4}$ DNA and ligand complexes.

\footnotetext{
${ }^{1}$ M. J. Frisch, et al. (2013) Gaussian 09, Revision D.01, Gaussian, Inc., Wallingford, CT.

${ }^{2}$ G. M. Morris, R. Huey, W. Lindstrom, M. F. Sanner, R. K. Belew, D. S. Goodsell, A. J. Olson, J. Comput. Chem. 2009, 30, 2785-2791.

${ }^{3}$ M. Rarey, B. Kramer, T. Lengauer, G. Klebe, J. Mol. Biol. 1996, 261, 470-489.
} 
15.0 NMR spectra of compounds

${ }^{1} \mathrm{H}$ and ${ }^{13} \mathrm{C}$ NMR of 5:
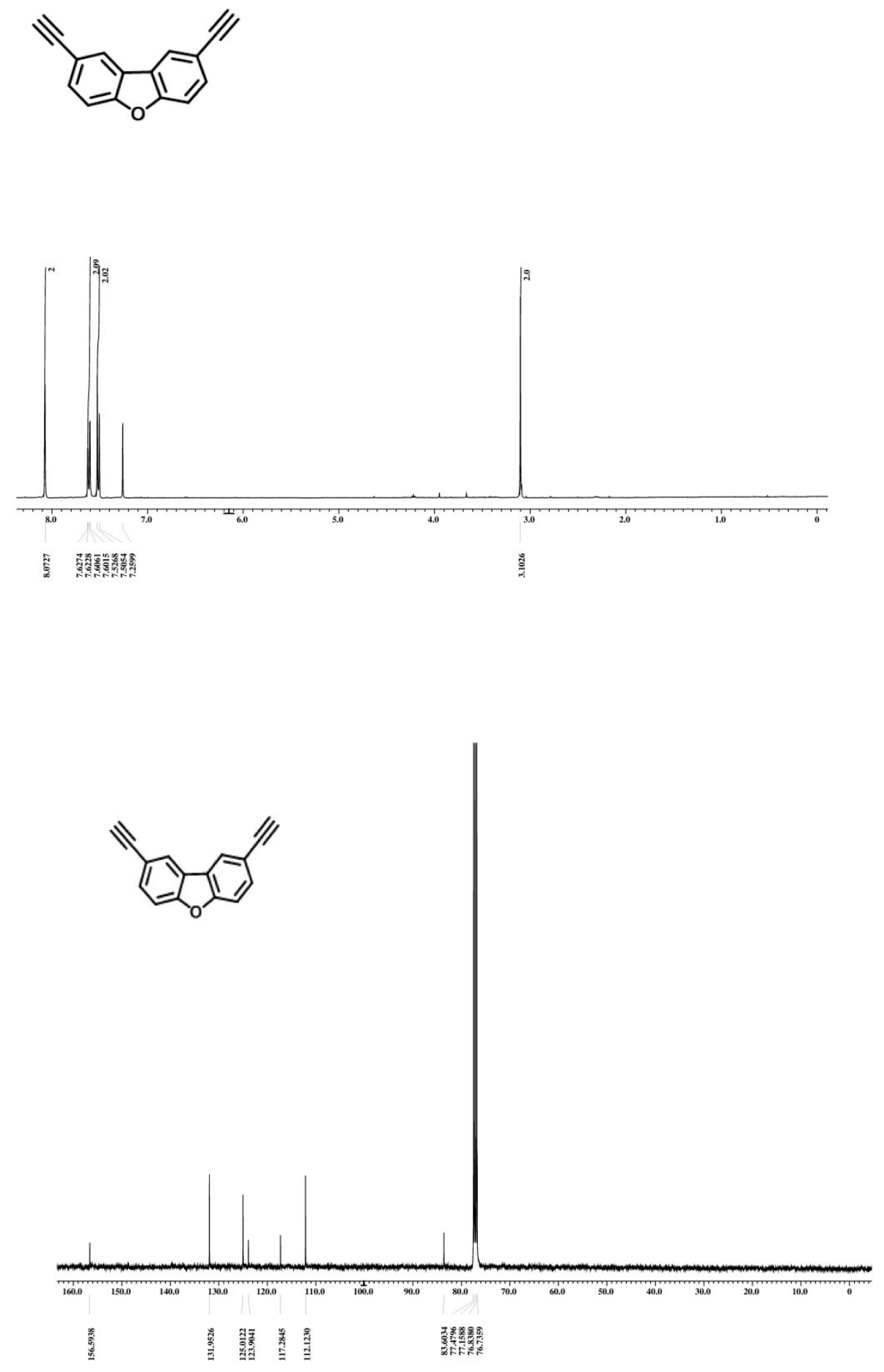

S21 
${ }^{1} \mathrm{H}$ NMR and ${ }^{13} \mathrm{C}$ NMR of 6 :
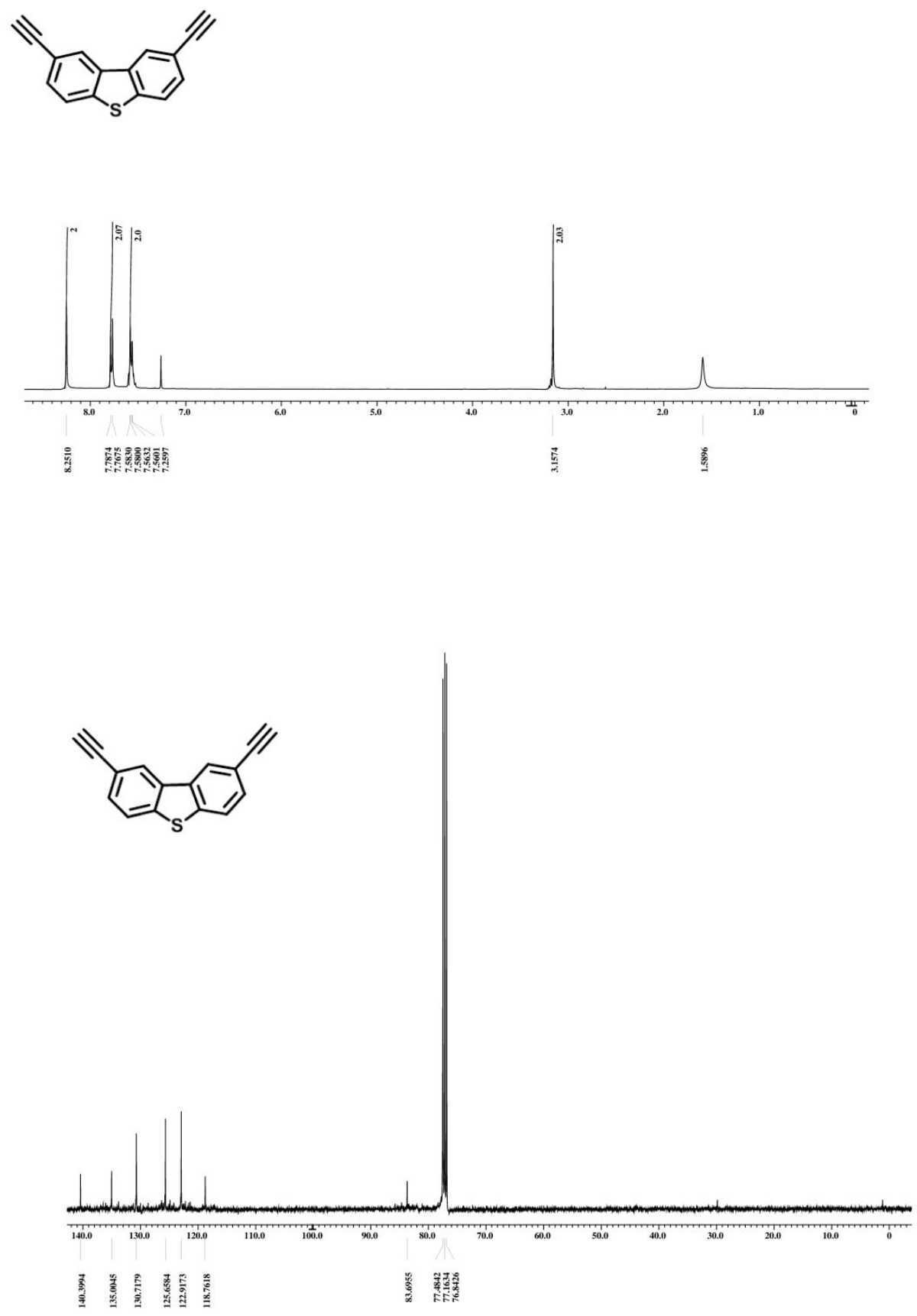
${ }^{1} \mathrm{H}$ and ${ }^{13} \mathrm{C}$ NMR of 8a:
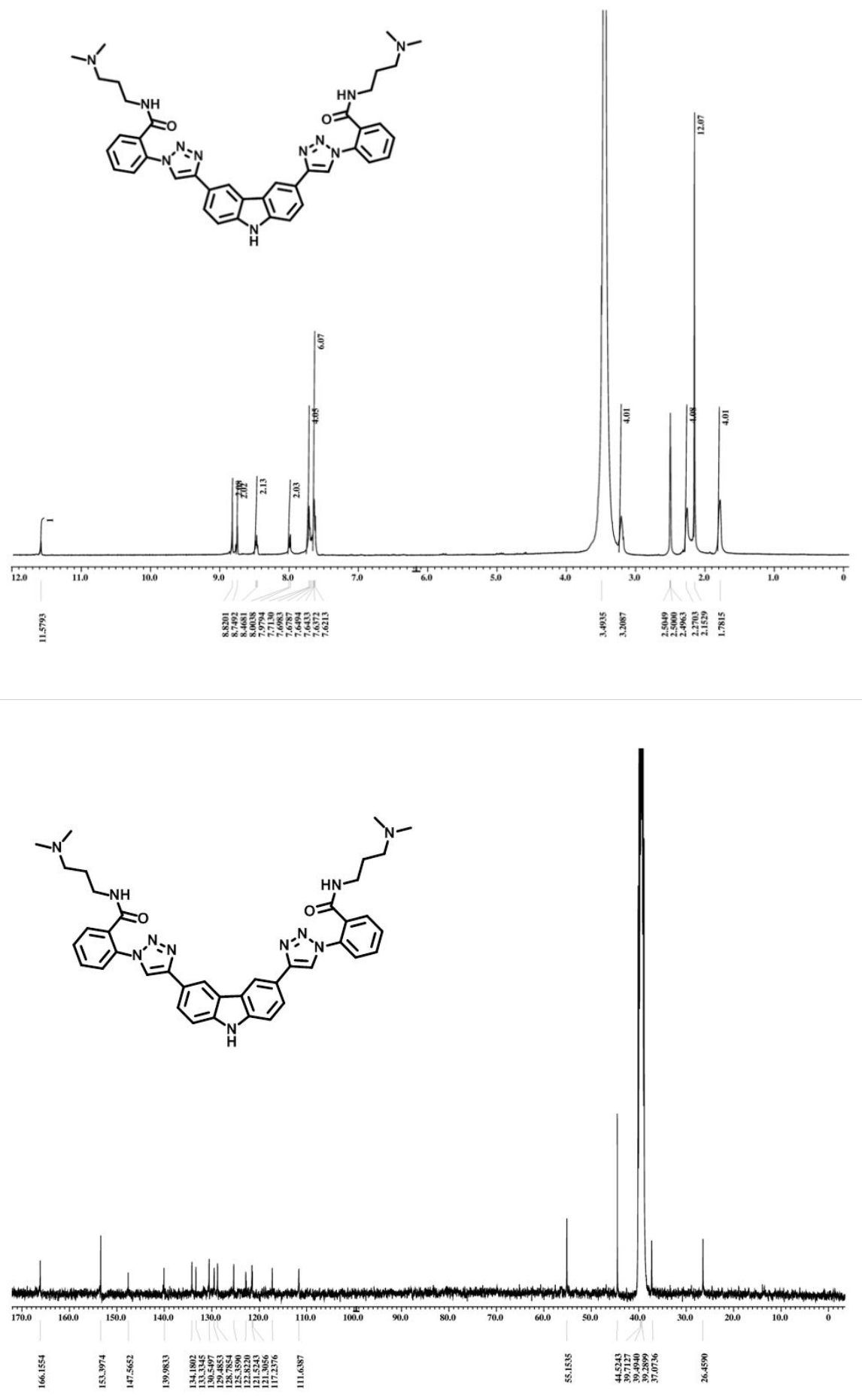
${ }^{1} \mathrm{H}$ and ${ }^{13} \mathrm{C}$ NMR of $8 \mathrm{~b}$ :
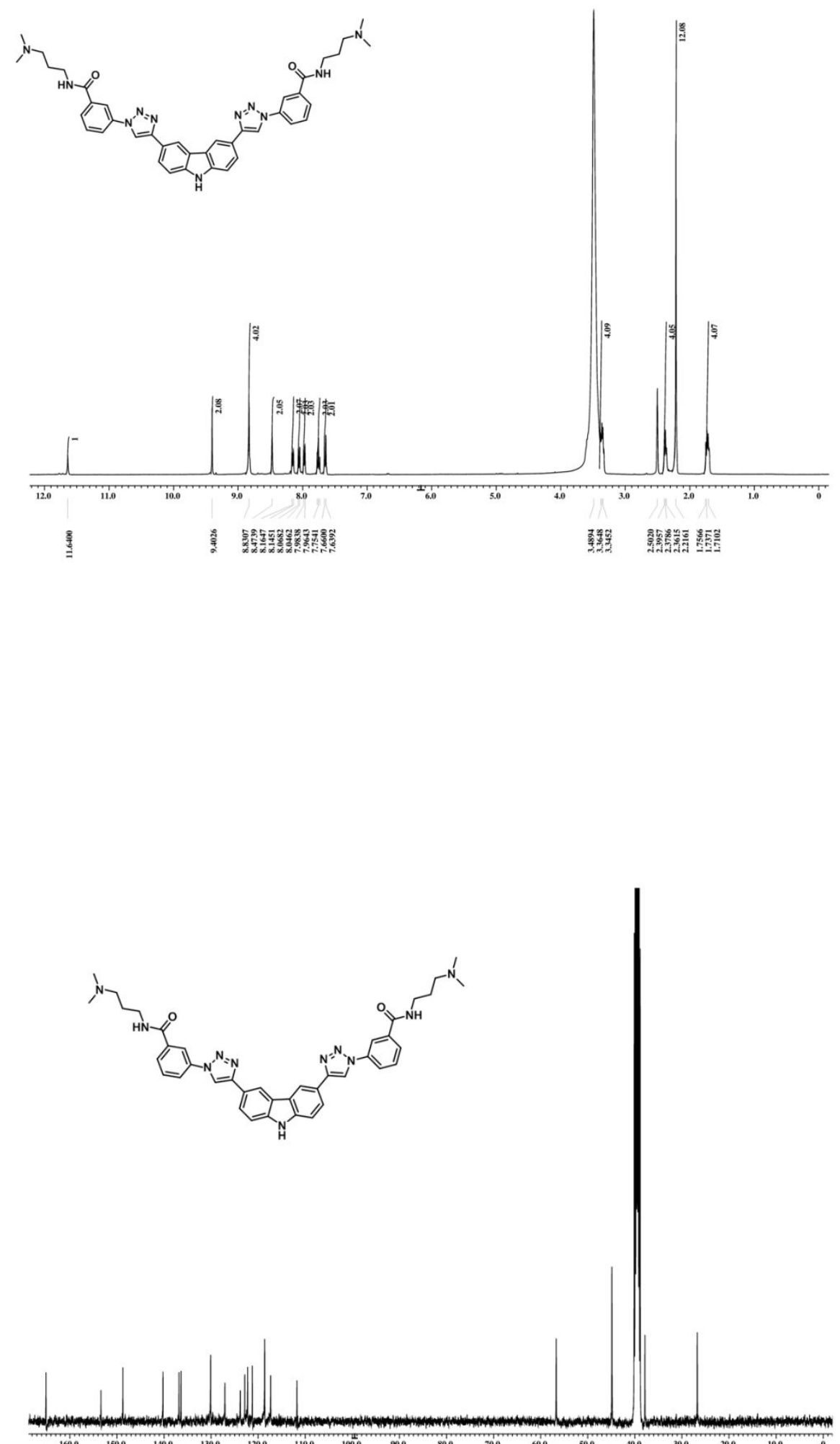

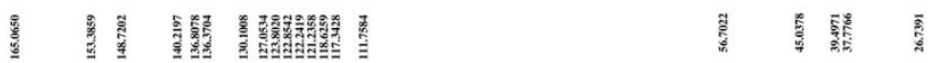


${ }^{1} \mathrm{H}$ and ${ }^{13} \mathrm{C}$ NMR of 9a:
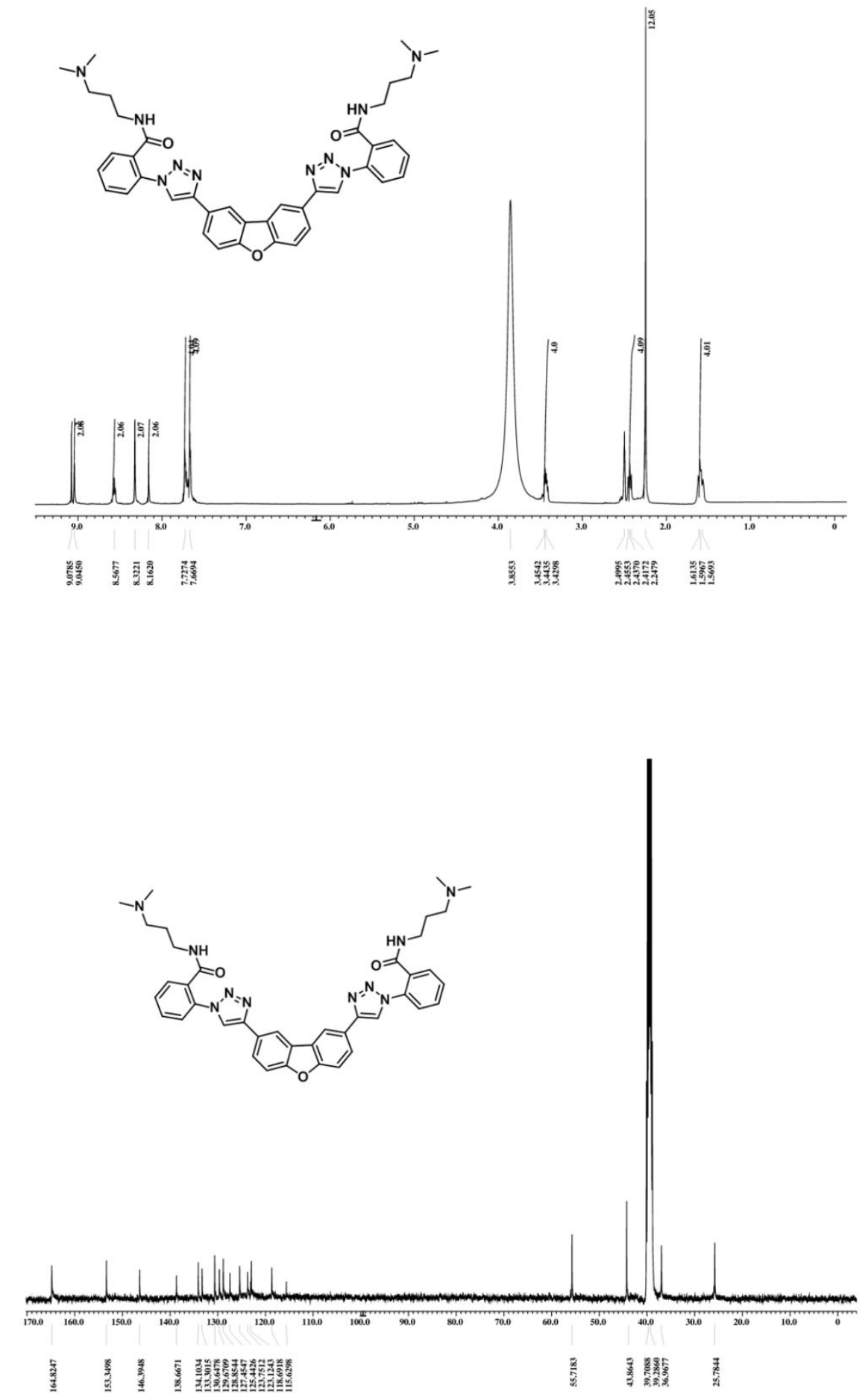
${ }^{1} \mathrm{H}$ and ${ }^{13} \mathrm{C}$ NMR of $9 \mathrm{~b}$ :
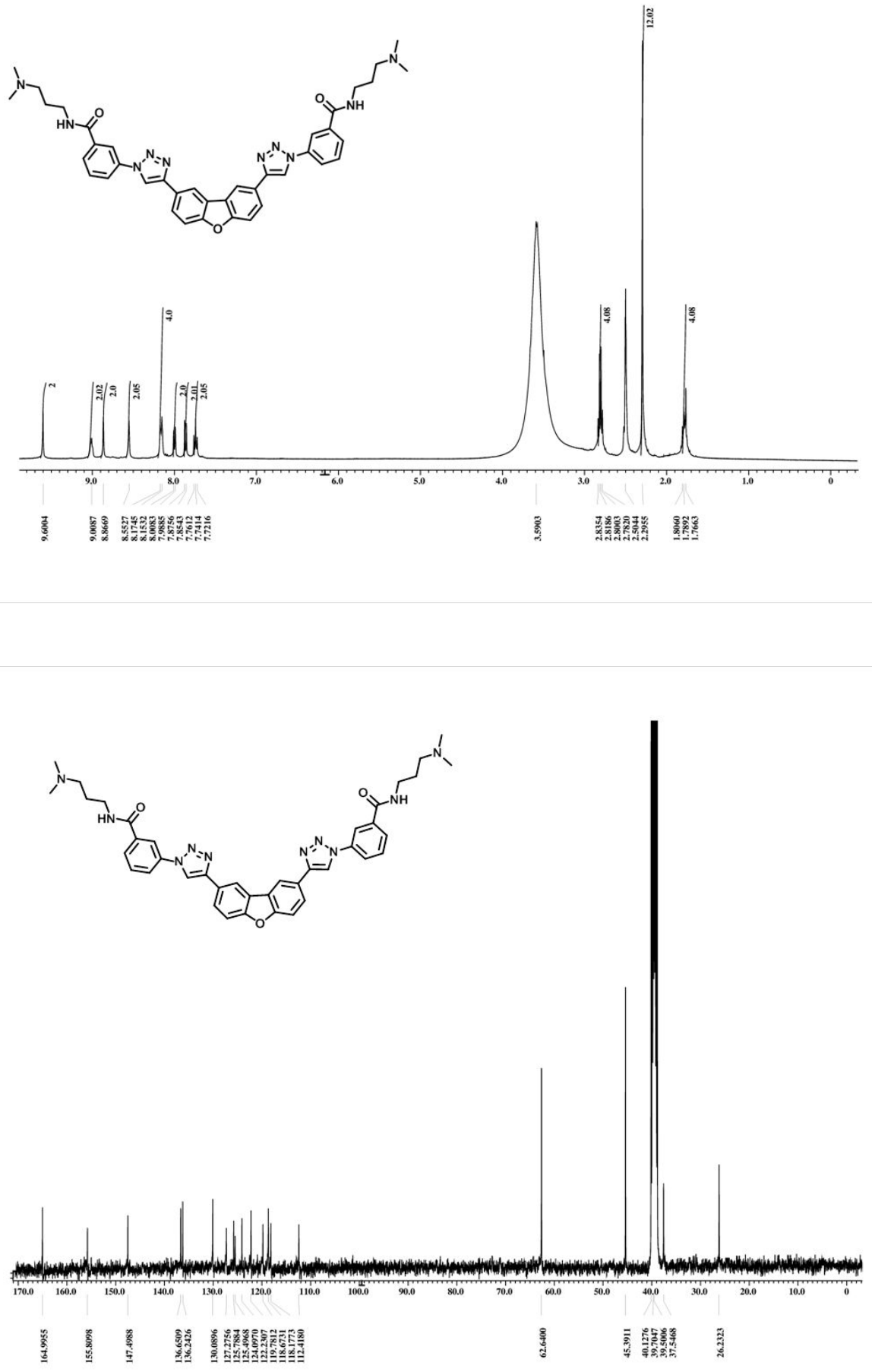
${ }^{1} \mathrm{H}$ NMR and ${ }^{13} \mathrm{C}$ of $9 \mathrm{c}$ :
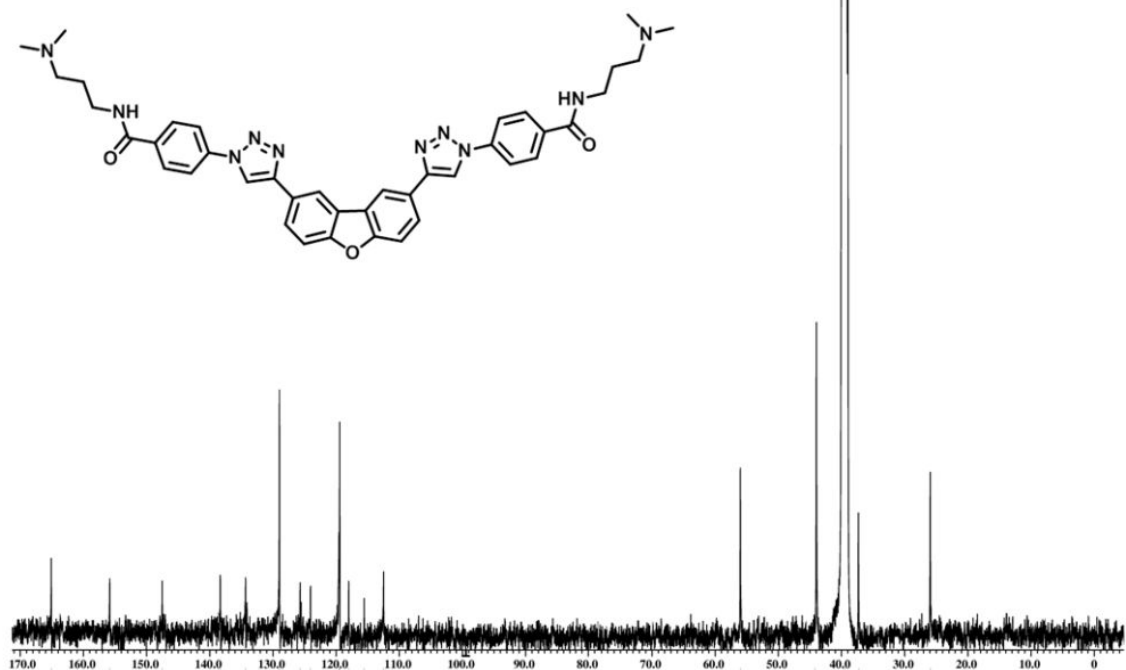

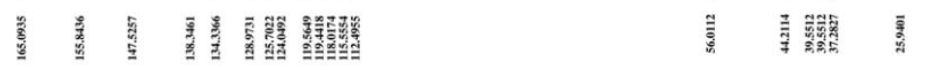
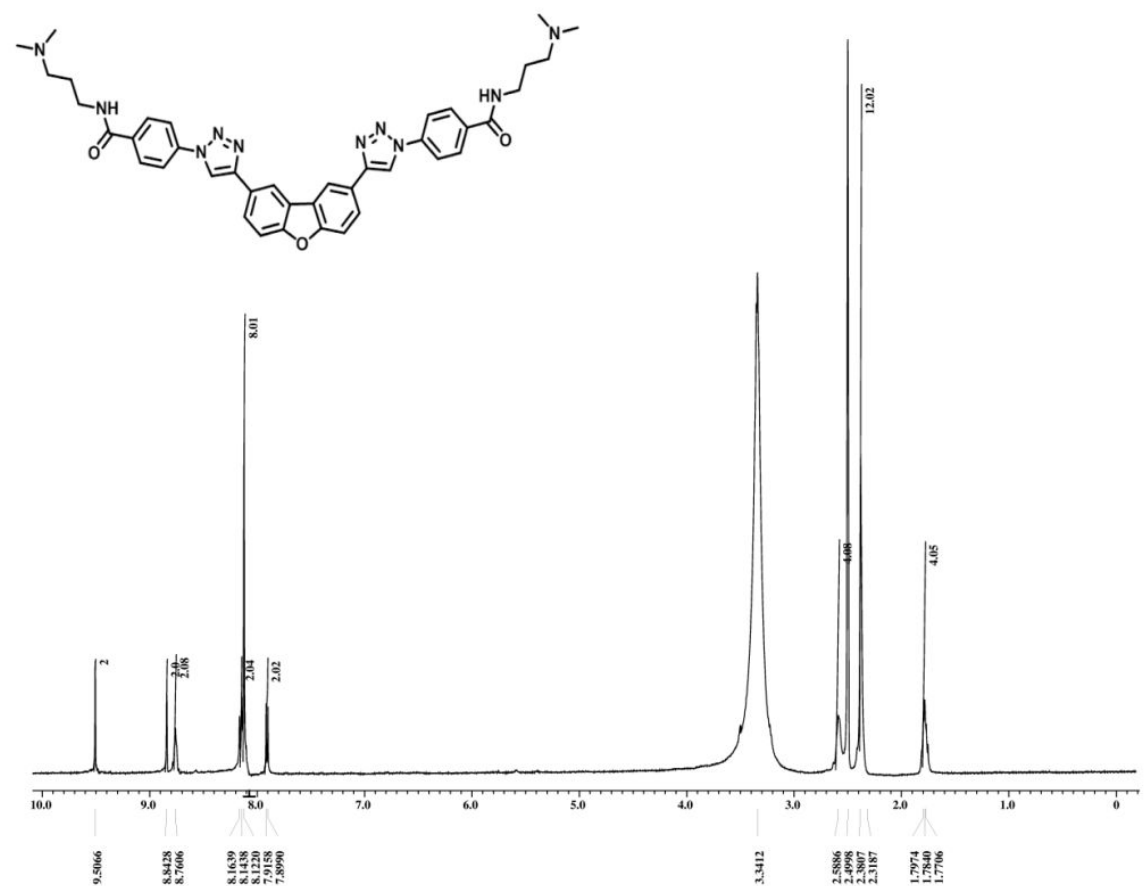
${ }^{1} \mathrm{H}$ and ${ }^{13} \mathrm{C}$ NMR of 10a:
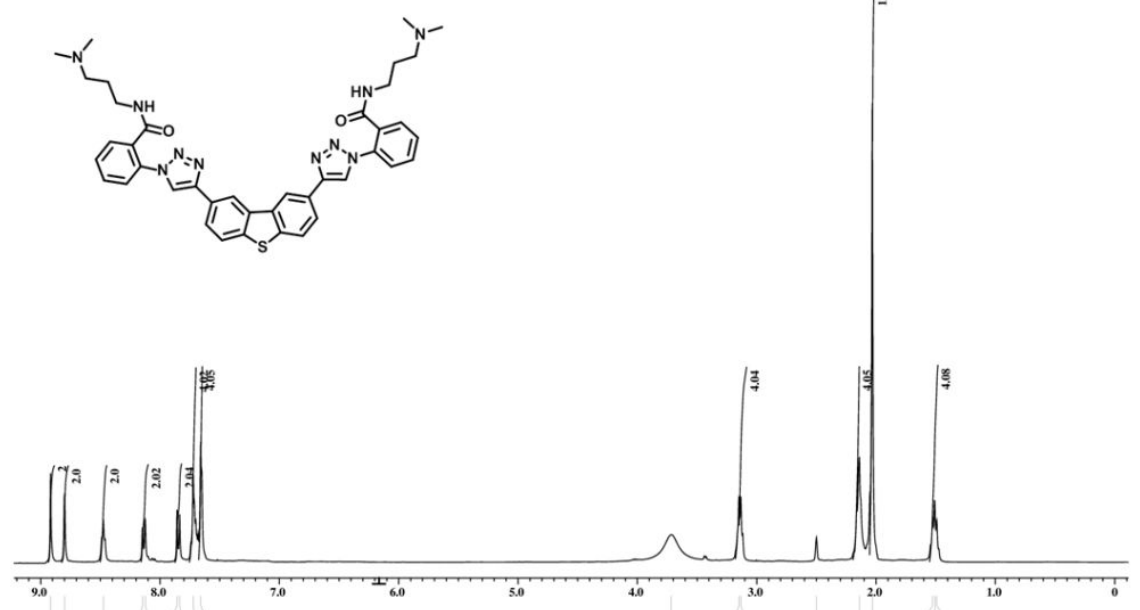

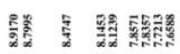
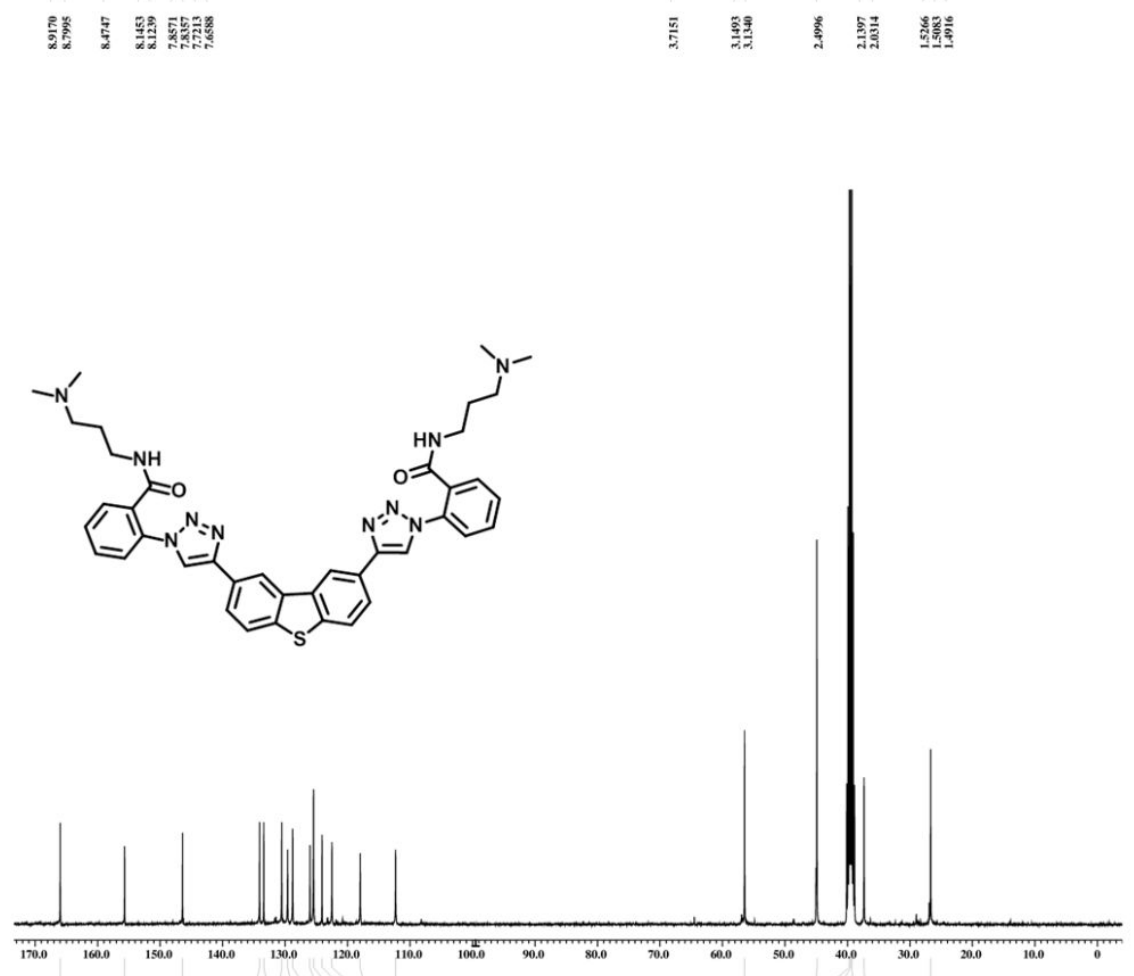

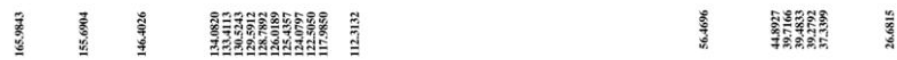


${ }^{1} \mathrm{H}$ and ${ }^{13} \mathrm{C}$ NMR of $10 \mathrm{~b}$ :
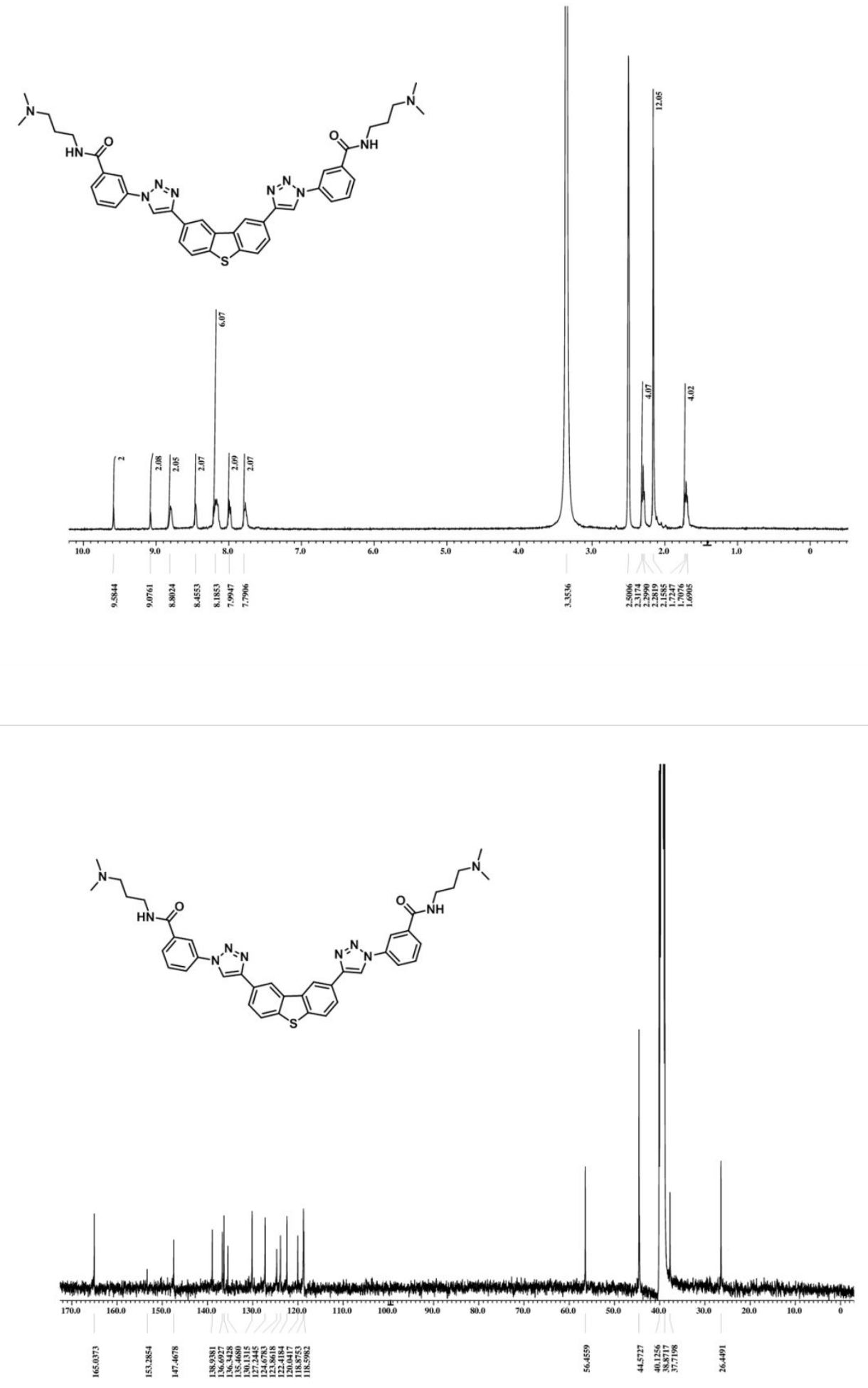
${ }^{1} \mathrm{H}$ NMR and ${ }^{13} \mathrm{C}$ NMR of 10c:
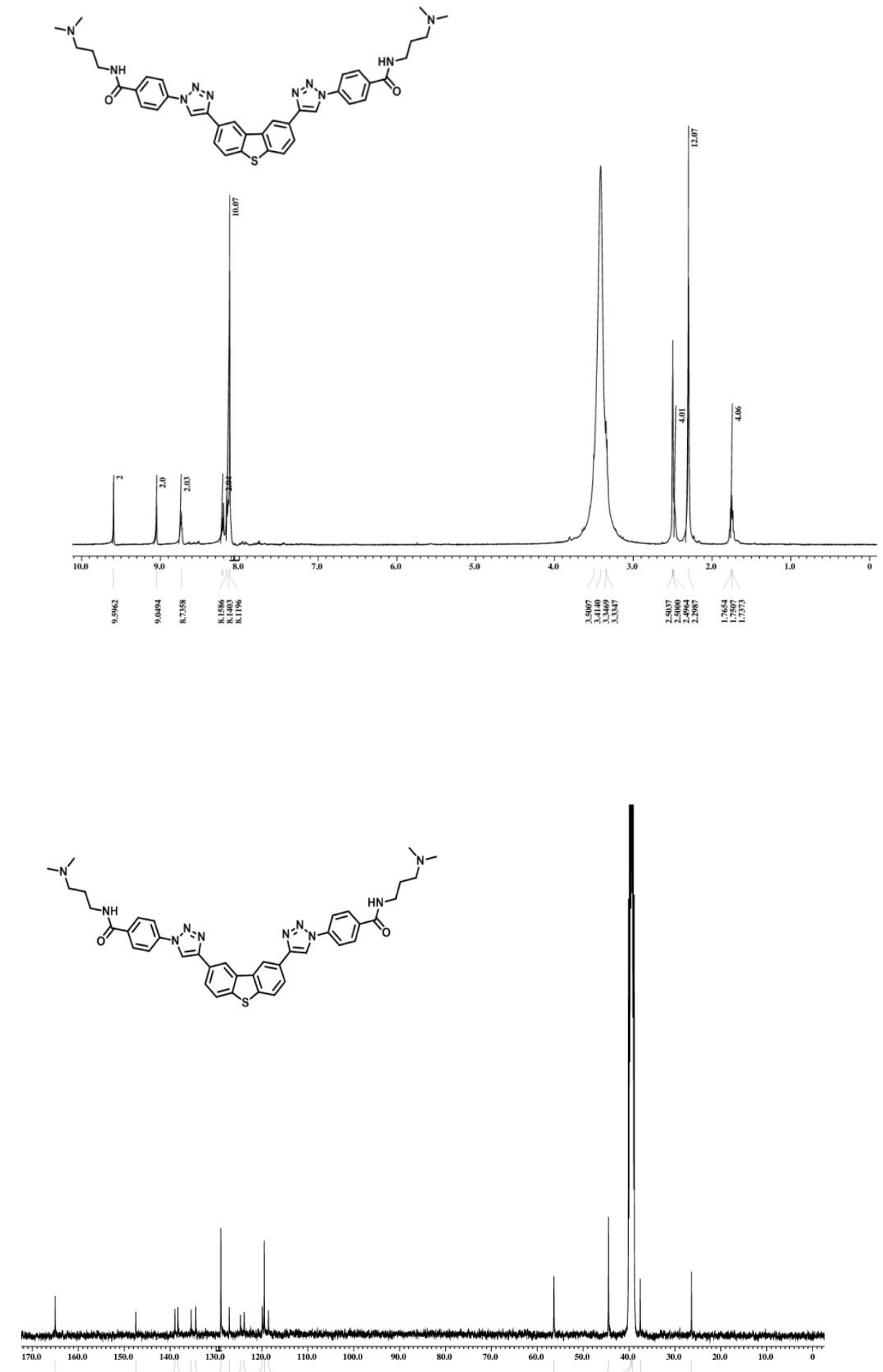

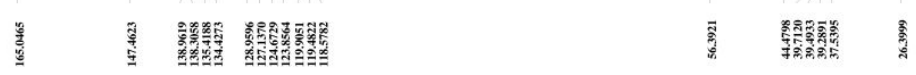

